



\section{Assisted Reproduction in the Nordic Countries}

A comparative study of policies and regulation 


\section{Assisted Reproduction in the Nordic Countries}

A comparative study of policies and regulation

TemaNord 2006:505

(C) Nordic Council of Ministers, Copenhagen 2006

ISBN 92-893-1272-6

Print: Akaprint A/S, Århus 2006

Cover: Kjell Olsson

Cover photos: Ingram

Copies: 600

Printed on environmentally friendly paper

This publication can be ordered on www.norden.org/order. Other Nordic publications are available at www.norden.org/publications

Printed in Denmark

Nordic Council of Ministers

Store Strandstræde 18

DK-1255 Copenhagen K

Phone (+45) 33960200

Fax (+45) 33960202

\section{Nordic Council}

Store Strandstræde 18

DK-1255 Copenhagen K

Phone (+45) 33960400

Fax (+45) 33111870

www.norden.org

\section{Nordic Committee on Bioethics}

The Nordic Committee on Bioethics was established 1988 to identify and survey ethical issues related to legislation, research and developments in biotechnology in the Nordic countries and internationally. The committee has two members from each Nordic country. It contributes to the public debate by organising workshops on selected issues, publishing reports and policy documents, and spreading information to national authorities and national ethics committees.

\section{Nordic co-operation}

Nordic co-operation, one of the oldest and most wide-ranging regional partnerships in the world, involves Denmark, Finland, Iceland, Norway, Sweden, the Faroe Islands, Greenland and Åland. Co-operation reinforces the sense of Nordic community while respecting national differences and similarities, makes it possible to uphold Nordic interests in the world at large and promotes positive relations between neighbouring peoples.

Co-operation was formalised in 1952 when the Nordic Council was set up as a forum for parliamentarians and governments. The Helsinki Treaty of 1962 has formed the framework for Nordic partnership ever since. The Nordic Council of Ministers was set up in 1971 as the formal forum for co-operation between the governments of the Nordic countries and the political leadership of the autonomous areas, i.e. the Faroe Islands, Greenland and Åland. 


\section{Table of Contents}

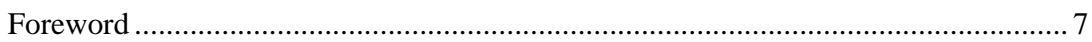

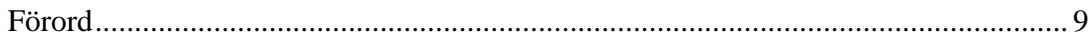

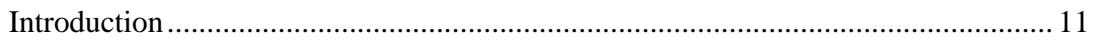

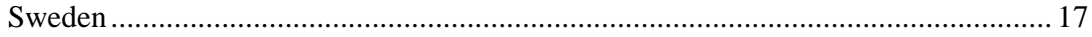

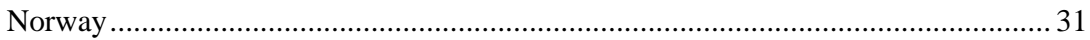

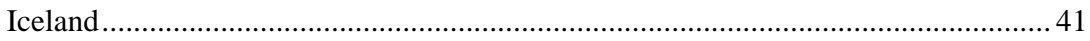

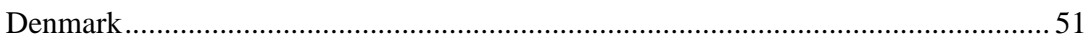

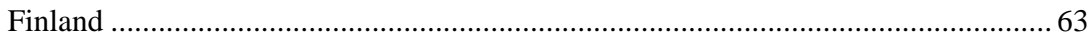

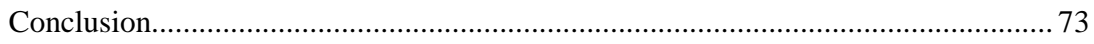

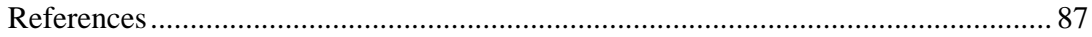

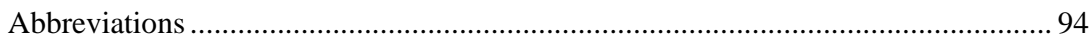

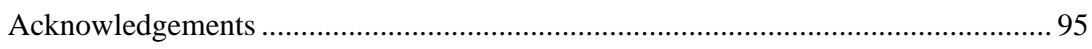

Appendix: Original names of central acts and governmental bodies ......................... 96 



\section{Foreword}

The aim of this publication is to provide insight into the backgrounds to the different legal situations regarding assisted reproduction in the Nordic countries

The Nordic Committee on Bioethics initiated in 2001 a project on the Nordic regulation of biotechnology, related ethical questions, and their reflections on political decision-making. This project resulted in the publication of "Legislation on biotechnology in the Nordic countries - an overview", 2003 which has now been updated and amended and can be found at www.ncbio.org.

In spite of common historical background, geography, language and culture, there is a great diversity in the legislation on biotechnology between the Nordic countries. The Nordic Committee on Bioethics was interested in understanding the basis for differences in the legislation, the social, cultural, and political aspects, as well as the decision making processes and implementation. The committee selected assisted reproduction as an example for further studies, because the legislation varied markedly between the Nordic countries, it had been passed at different time points, and assisted reproduction had been practiced in all the Nordic countries for decades.

In early 2003 The Nordic Committee on Bioethics announced a call for proposals to "A comparative study which looks at the backgrounds to the different legal situations regarding assisted reproduction in the Nordic countries. The study should be conducted by a senior scientist with experience from the social, cultural or juridical field. The aim of the study is to look into the various backgrounds and processes which have led to different legal situations regarding assisted reproduction in the Nordic countries.

A second purpose of the study is that it should serve as a pilot study and form the basis for possible further research into the cultural foundations and values which is the base for the legislation and which might explain the differences between the individual countries." 
In the announcement for the call it was also clarified that the project was to be conducted independently by the scientist. A reference group consisting of members and the secretary of the Nordic Committee on Bioethics, was assigned to help and advice throughout the project.

The reference group evaluated the proposals and selected a proposal submitted by Dr. Riitta Burrell, which was approved by the Committee. A contract was made between the Committee and Riitta Burrell, who started the project in July 2004.

Riitta Burrell is a researcher in medical law, specialising in legal, ethical, and comparative aspects of assisted reproduction. She has written several articles and presented numerous papers both at national and international conferences on assisted reproduction, abortion, and the status of the fetus. She received the degree of Doctor in Laws in October 2003 at the University of Helsinki.

First and foremost the Nordic Committee on Bioethics wishes to thank Dr. Riitta Burrell for her excellent work. The work of the reference group Dr. Mette Hartlev, (University of Copenhagen, Denmark), Prof. Susanne Lundin (University of Lund, Sweden), Dr. Katarina Westerlund (Uppsala University, Sweden) and Helena von Troil, the Committee secretary, is duly acknowledged, and so are useful comments from Committee members on issues related to their respective countries. Special thanks to Dr. Salla Lötjönen (University of Manchester, United Kingdom) and Helena von Troil for assisting with the preparation of the report and its publication.

The Nordic Committee on Bioethics gratefully acknowledges the support of the Nordic Council and the Nordic Council of Ministers, providing the funds for the project.

October 2005

Ingileif Jónsdóttir

Chairman 


\section{Förord}

Målet med denna publikation är att ge insikt i bakgrunden till de olika juridiska situationerna gällande assisterad befruktning i de nordiska länderna.

Nordisk kommitté för bioetik tog år 2001 initiativ till ett projekt om regleringen av bioteknologi i Norden, etiska frågor och hur de avspeglas i politisk beslutsfattning. Detta projekt resulterade i publikationen Lagstiftning om bioteknologi i Norden - en översikt, 2003. Tabellerna har nu uppdaterats och utökats och finns på kommitténs hemsida www. ncbio.org.

Trots gemensam historisk bakgrund, geografi, språk och kultur finns det stor variation i lagstiftningen om bioteknologi i de nordiska länderna. Nordisk kommitté för bioetik var intresserad av att förstå grunden för dessa olikheter, de sociala, kulturella och politiska aspekterna samt beslutsprocesserna och implementeringen. Kommittén valde assisterad befruktning som ett exempel för vidare studier för att lagstiftningen var mycket olika i de olika länderna, lagarna hade stiftats vid olika tidpunkter och assisterad befruktning har utövats i alla de nordska länderna i tiotals år.

I början av 2003 utlyste Nordisk kommitté för bioetik möjligheten att söka finansiering för en jämförande studie rörande bakgrunden till de olika juridiska situationerna om assisterad befruktning i de nordiska läderna. Studien skulle utföras av en äldre forskare med erfarenhet från det sociala, kulturella eller jurdiska området. Målet med studien är att få en inblick i bakgrunden och processerna som lett till att situationen är så varierande i de olika länderna. Ett annat mål med studien är att den skall kunna fungera som pilotundersökning och utgöra basen för eventuell fortsatt forskning i kulturen och de olika värden som utgör grunden för lagstiftningen och som kunde förklara skillnaderna mellan länderna. Det 
klargjordes också att forskaren självständigt skulle genomföra projektet. En referensgrupp bestående av kommittémedlemmar och dess sekreterare utsågs för att hjälpa och rådgiva under projektets gång.

Referensgruppen utvärderade ansökningarna och valde den som gjorts av dr. Riitta Burrell. Projektet godkändes av kommittén och ett kontrakt gjordes mellan kommittén och Riitta Burrell, som inledde projektet i juli 2004.

Riitta Burrell är forskare i medicinsk juridik och hon har specialiserat sig på juridiska, etiska och jämförande aspekter på assisterad befruktning. Hon har skrivit flera artiklar och varit talare vid många nationella och internationella konferenser om assisterad befruktning, abort och fostrets status. Hon doktorerade i juridik vid Helsingfors universitet år 2003.

Nordisk kommitté för bioetik vill först och främst tacka dr. Riitta Burrell för hennes utmärkta arbete. Kommittén vill även uttrycka sin tacksamhet till referensgruppen som har bestått av dr. Mette Hartlev (Köpenhamns universitet, Danmark), prof. Susanne Lundin (Universitet i Lund, Sverige), dr. Katarina Westerlund (Uppsala universitet, Sverige) och Helena von Troil, kommitténs sekreterare samt till övriga kommittémedlemmar som gjort nyttiga kommentarer till frågor in anknytning till de olika länderna. Ett speciellt tack riktas till dr. Salla Lötjönen (Universitet i Manchester, Storbritannien) och Helena von Troil för hjälp med sammanställandet av rapporten och dess publicering.

Slutligen vill Nordisk kommitté för bioetik tacka Nordiska Rådet för stödet den fått samt Nordiska Ministerrådet för finansieringen av projektet.

Oktober 2005

Ingileif Jónsdóttir

Ordförande 


\section{Introduction}

A variety of methods to overcome human infertility has been practiced since biblical times. Assisted reproduction in its contemporary form has evolved from 'low-tech' procedures of artificial insemination, first performed in the latter part of the $19^{\text {th }}$ century. The 'high-tech' methods of assisted reproduction or the so-called assisted reproductive technologies (ARTs) refer to medical interventions in which both eggs and sperm are handled in order to accomplish a pregnancy. Assisted reproduction in its high-tech form is a fairly recent innovation dating back to the birth in 1978 in Great Britain of Louise Brown, the first baby born following in vitro fertilization (IVF). ${ }^{1}$

In terms of clinical practice, the Nordic countries have an excellent track record in the field of assisted reproduction. According to a survey (Andersen, Gianaroli \& Nygren 2004) performed by the European IVFmonitoring program (EIM) ${ }^{2}$ for the European Society of Human Reproduction and Embryology (ESHRE), the availability of fertility services is the highest in Denmark, followed closely by the other Nordic countries. Also the proportion of test-tube babies to all children born in 2000 was the highest in the Nordic region. The report includes data on multiple pregnancies, which are closely related to maternal and fetal safety. ${ }^{3}$ According to the EIM report, Denmark, Finland, and Sweden have a low

\footnotetext{
${ }^{1}$ Although ART is a narrower concept than assisted reproduction, assisted reproductive technology and assisted reproduction are used interchangeably in this report.

${ }^{2}$ EIM collects ART data from 22 European countries. The most recent EIM report covers treatment cycles initiated during 2000 (Andersen, Gianaroli \& Nygren 2004).

${ }^{3}$ The more embryos are transferred in IVF and ICSI cycles, the greater is the likelihood of a multiple pregnancy. Multiple pregnancies are associated with greater risks than singleton pregnancies.
} 
proportion of three-embryo transfers. ${ }^{4}$ Finally, out of the 22 participating countries, only nine have complete coverage in their reporting system. All the Nordic countries are among those nine.

However, assisted reproductive technologies are not merely clinical procedures. Not only do they eliminate the need for sexual intercourse but, for the first time in human history, provide the possibility of breaking the genetic connection between the child and the woman who carries it. In addition, as Eric Blyth and Ruth Landau point out, "the standard IVF technique allows any egg to be fertilized with any sperm, and allows the providers of the genetic material to remain anonymous to the recipients" (Blyth \& Landau 2004, 8). Because of their capability to change the nature of human reproduction in profound ways, assisted reproductive technologies raise a unique set of concerns about safety and well-being, legal rights and obligations, and right and wrong.

The social, ethical, and legal issues regarding assisted reproduction are differently interpreted, assessed and dealt with in different countries. By now, most European nations have adopted laws to regulate assisted reproduction. These laws reflect a variety of cultural, religious, political, and economic values and preferences, testifying to the complex nature of assisted reproduction.

In the course of the 1980s and 1990s all Nordic countries, with the exception of Finland, have implemented policies to regulate the use of assisted reproductive technologies. Policies or policy designs are, according to Goggin et al., "authoritative decisions, meaning that the decisionmakers have the power (...) to force compliance through sanctions" (Goggin et al. 2004, 7; italic in the original). Although policy designs can take a number of forms, ART policy designs in the Nordic countries have been codified as acts passed by the national parliaments. In the absence of a comprehensive ART policy design the practice of assisted reproduction in Finland rests primarily on the self-regulation by the practitioners.

Against the background of a broad range of similarities in politics and culture, the Nordic countries display an unexpected divergence in their ART policies. In the absence of a comprehensive policy design Finland has, by default, the most permissive regimen of ART practices in the Nordic region. At the European level, the provision of assisted reproduc-

\footnotetext{
${ }^{4}$ The figures from Iceland were also below the European average. Data from Norway was not available.
} 
tion in Finland resembles closely the situation in Belgium. Neither Finland nor Belgium has specific ART legislation in force. The situation may change drastically if a law is passed eventually. Norway is at the opposite end of the permissive - restrictive scale. Compared to the other Nordic countries, Norway has the strictest ART regulation in place. At the European level, it can be found in the same restrictive category as Germany, Switzerland, and, most recently, Italy. The ART policy design in Iceland and Denmark places those two countries in the intermediate category together with Spain, France, the United Kingdom, and the Netherlands. While the policy design in the other Nordic countries has remained relatively constant, Sweden has through several re-designs moved from a rather restrictive policy design to a permissive one. Also the Icelandic government has recently indicated its willingness to move towards a more permissive design.

Assisted reproductive technologies, along with all new technologies, integrate into societies through social, cultural, and political appropriation processes (Jamison 2002). These processes occur at several different levels: in language through assimilation; in media through dissemination; in rules through normalization; in customs through habituation; and so on. There are also geographical differences as appropriation processes vary "from place to place, due to particular local contingencies, both natural and social, political and economic, but also due to different 'ways of life', different patterns of culture" (Jamison 2002, 100).

This report examines the appropriation of assisted reproductive technologies in the Nordic countries at the level of policy-making. It traces the policy designing process in each country from governmental committees or working parties to parliamentary proceedings. It describes formative events and debates. In the end, the report identifies some of the factors that account for the divergence of ART policies among the Nordic countries.

In its search for answers, this study borrows some of the key concepts and methods used by the so-called Comparative Policy Design Project (CPDP). CPDP is a comparative study of ART policies and policy designing processes in nine European and two North American countries (Bleiklie et al. 2004). Of particular relevance in the present context is the Comparative Policy Design Framework chosen by the CPDP to help explain policy design including "goals, the means (or instruments) chosen to 
achieve them, and definition of target groups. The framework posits that these design choices will be the product of: (1) characteristics of the participating actors, including their beliefs, interests, resources, and relations with each other; (2) institutional rules, norms, and habits that either constrain or shape the designing process and resulting design choices; (3) the nature of the policy designing process itself, which, though structured by predictable factors, is nonetheless dynamic and probabilistic; and (4) the broader context of circumstances, knowledge and opinion, which influences the beliefs, interests, and resources of the participants, and therefore their relations with each other" (Goggin et al. 2004, 5-6).

The present study incorporates two complementary methodologies: empirical legal research and qualitative comparative analysis. Empirical legal research is a method of analyzing the operations and the effects of the law. It involves an in-depth exploration of legal processes, typically focusing on a modest number of interactions but viewing them from a variety of perspectives and over time. The strength of this approach lies in its capacity to reflect the complexity of legal processes, and the complexity of the relationship between process and outcome (Baldwin \& Davis 2003).

In addition, the study also relies on qualitative comparative analysis. Qualitative comparative analysis allows for comparison where the number of cases under investigation is more than two, but fewer than the large number normally associated with statistical or quantitative analysis (Keohane et al. 1994; Ragin 1987). In this particular case, it allows for the comparison of the Nordic countries. This study adapts qualitative comparative analysis to the area of public policy in assisted reproduction following loosely the work of the CPDP.

The study provides an explanation for the variation in ART policies in the Nordic countries by investigating a set of five explanatory factors:

1) party politics; the beliefs and interests of political parties

2) self-regulation of assisted reproductive technologies by the physicians and researchers

3) mobilization of interest groups; e.g. patients, religious groups, and feminists

4) policy transfer, i.e. lesson-drawing, across countries

5) other considerations; e.g. formative events and public debates 
The study relies on a variety of archival materials including parliamentary documents and committee reports. In addition, it utilizes more than 30 personal interviews conducted in the five Nordic countries from the autumn of 2004 to the winter of 2005. The selection of the interviewees was based on two main criteria: first, the interviewees' involvement in the ART policy design process as members of an ART committee or working group, as officials at the ministry responsible for drafting ART legislation, or as members of parliament, and secondly, their expertise in reproductive medicine, health law, family law, or health policy.

The chapters on the individual Nordic countries are placed in the order in which each country implemented legislation on assisted reproduction. Sweden has been the Nordic leader in assisted reproduction. It was the first country in the world to pass a law on artificial insemination. The Swedish experience on the Insemination Act of 1985 has been followed with keen interest not only in the Nordic region but globally as well. Furthermore, Sweden was one of the first countries in the world to produce a government report on in vitro fertilization. The report, written by the same Insemination Committee whose preparatory work led to the Insemination Act, came out in 1985. Finally, the first Nordic test-tube baby was born in Gothenburg in 1982. Since Sweden is a definite forerunner in the field of assisted reproductive technologies, its policy design process and the two committee reports have been examined in detail in this study. The second country in order, Norway, passed the Act on Artificial Fertilization in 1987. The 1987 Act has been said to be the world's first national law to cover the entire field of assisted reproduction. It has also been said that the Norwegian law was inspired by the work of the Swedish Insemination Committee. Iceland and Denmark were the next group of Nordic countries to implement ART legislation in the 1990s, Iceland in 1996 and Denmark in 1997. Finland is the last one in order since no law on assisted reproduction has been enacted in the country as of yet. 



\section{Sweden}

The Swedish Insemination Act, which entered into force in 1985, was the first of its kind in the world. A provision in the Act giving the donor-conceived child a right to obtain identifying information on the donor has been heralded as revolutionary and unique. The Swedish experience has been watched closely around the world with an increasing number of countries developing their legislation modeled on the Swedish law. Despite all the outside interest, the Insemination Act was received, originally at least, with a fare amount of skepticism by the Swedish medical community. The abolishment of donor anonymity was at the center of their criticism. Even before the introduction of the 1985 Act, as the Insemination Committee was working on its proposal, doctors predicted an imminent and irreversible decline in the number of sperm donations. A significant decline did indeed take place after the Insemination Act was passed. Moreover, it appears that a shortage of donors continues to plague the provision of donor insemination in Sweden.

Although Swedish legislation in the domain of assisted reproduction and biomedical research is quite liberal today, this was not the case initially. The process of liberalization has been gradual, marked by a series of legislative actions scattered over a span of two decades. These include permitting in vitro fertilization in 1988, embryo research in 1991, egg donation in 2003, and the creation of embryos for research purposes in 2005. In June 2005 the Swedish parliament, Riksdag, approved a bill allowing lesbian couples to have access to assisted reproduction.

At the initiative of the Swedish Society of Medicine in December 1981 the government appointed Tor Sverne as a special examiner to investigate the issue of artificial insemination. Sverne, the Parliamentary Commissioner for the Judiciary and the Civil Administration, had previously led the Commission on Children's Rights with the task of exploring how the legal position of children in Sweden could be strengthened. ${ }^{5}$ Sverne's

5 In the first of its interim reports (SOU 1978:10) the Commission recommended a ban on corporal punishment and other offensive treatment of children. The recommendation resulted in 
previous role as the chairman of the Commission on Children's Rights may help to explain, in part at least, the strong emphasis that the Insemination Committee placed on the legal protection of children.

Another crucial element of the Insemination Committee's work was the analogy it drew between donor insemination and adoption: "Parents of a child conceived by AID are in approximately the same situation as adoptive parents. The issue is in both cases the fact that at least one of the parents is not the natural parent of the child with the problems which this may entail. The Committee finds strong reasons in favor of drawing parallels between adoption and AID to the greatest possible extent when it comes to society's attitudes to the issue. At present, however, the approach to the problem varies considerably according to what alternative adoption or AID - is chosen by the childless couple” (SOU 1983:42, 203).

The Committee pointed out that in the case of adoption there was an organized activity built up under public auspices and statutory rules and norms laid down in order to protect the adopted child. No such publicly organized activity existed in the domain of donor insemination. For instance, in the case of donor insemination, no psychosocial investigation in order to establish the suitability of the prospective parents was undertaken. The husband or the cohabitant of the woman receiving treatment was not legally and irrevocably bound to his donor-conceived child. And there existed no possibility for a donor-conceived child to obtain information as to who was his or her biological father (SOU 1983:42, 203-210).

Towards the end of the Committee's mandate, a decision by the Swedish Supreme Court lent a sense of urgency to concerns over the legal status of donor-conceived children. In March 1983 the Supreme Court decided in favor of a man who, after a divorce, requested that his paternal rights and obligations be terminated since the child was conceived via donor insemination. In the Committee's opinion, Swedish society's attitude to donor insemination was no longer acceptable: “A self-evident

the introduction of a new piece of legislation prohibiting corporal punishment in 1979. In its 1979 report (SOU 1979:63) the Commission issued a number of recommendations on custody, right of access, and transference of children in cases of disputed custody. These recommendations were based on a presentation of the Commission's views as to what fundamental needs a child has a right to have satisfied, which included the right of the child to physical and mental care, security, understanding for his or her particular needs and abilities, and the right to upbringing and education (SOU 1979:63, 21). 
prerequisite for permitting the undertaking of AID should be - as in the case of adoption - that the needs and interests of the prospective child be satisfied and safeguarded" (SOU 1983:42, 204).

The Committee's emphasis on the legal protection of children was most apparent in the context of the donor-conceived child's right to know his or her origin. At the time of the drafting of the report, the protection of privacy and secrecy in donor insemination was the norm not only in Sweden but around the world. In Sweden, many hospitals routinely destroyed the donor records as soon as a pregnancy had been achieved, thereby ensuring that the donor could never be identified later (SOU 1983:42, 203). The mother and non-biological father registered themselves as the child's parents and were encouraged not to tell the child or anyone else about the insemination (see Gottlieb et al. 2004, 2). Invoking again the adoption analogy the Committee pointed out that adoptive children in Sweden had a legal right to access to information on their biological parents. They were also entitled to assistance from public authorities in their search for their biological parents. Furthermore, according to the Committee, studies of adopted children revealed a profound need to know about one's biological origins.

Basing on the adoption analogy the Committee proposed that records on the donor and on the woman receiving treatment be kept for the future (SOU 1983:42, 216). However, the Committee acknowledged that, as a practical matter, a donor-conceived child may never be informed by his or her parents about the manner in which he or she was conceived. The Committee found this prospect deplorable. Nevertheless, although the Committee felt that "an open and honest relationship between parents and child certainly is an important prerequisite for the child's favorable development," it did not find it feasible to enforce such a relationship by law. Instead, the Committee urged health care personnel to inform and educate the prospective parents about the importance of openness to the child (SOU 1983:42, 212). ${ }^{6}$

\footnotetext{
${ }^{6}$ According to a Swedish legal expert, there may be another factor to be found behind the Committee's proposal - and eventually the Riksdag's decision - to abolish donor anonymity: "We have been keeping track of people for hundreds and hundreds of years and I think there is a picture of the importance of knowing your genetic origins that we have inbred in our system.” Not only donor-conceived children's psychological needs, but also the country's well-established tradition of keeping population statistics may therefore explain the provision, which made the Swedish legislation unique in the 1980s.
} 
The Committee was unanimous in all but one of its recommendations. The issue of the child's right to know his or her origin generated a lone dissent. Marc Bygdeman, a professor of obstetrics and gynecology at the Karolinska Institute, pointed out that anonymity was a prerequisite condition for donor participation. According to Bygdeman, a law giving donorconceived children a right of access to donor information would have a detrimental effect on this treatment method: "There is a full agreement among physicians engaging in AID that the removing of the anonymity protection of the donor would markedly reduce the extent of the insemination activity" (SOU 1983:42, 219).

Bygdeman's evaluation turned out to be correct on two accounts. First, it appears that a great deal of infertility doctors in Sweden were indeed opposed to the provision on the child's right to donor information. For example, a group of gynecologists wrote in the Dagens Nyheter in April 1984 that the forthcoming legislation was based on a scientifically unverified hypothesis regarding children's need for knowledge about their biological origin (see Daniels \& Lalos 1995, 1871). In his article entitled "The Swedish Insemination Act and Its Impact" (1994), Ken Daniels, a professor of social work from New Zealand who conducted several studies on semen donors in Sweden in the 1990s, reported that "one medical colleague (...) informed the author during a visit to Sweden in 1993 that not one of the general hospital clinic doctors was in favor of the legislation and that doctors wanted services to decline, so that the legislation would have to be changed. Another colleague has talked of the desire of doctors to sabotage the legislation” (Daniels 1994, 438).

Secondly, donor insemination did decrease noticeably in Sweden after the 1985 Act came into force. In fact, according to a group of four infertility specialists from the (former) Östra Hospital in Gothenburg, reporting in a 1990 issue of the Läkartidningen a decrease in sperm donations started already before the 1985 Act took effect due to the debate surrounding the preparatory work by the Insemination Committee. In their article entitled "Donor Insemination for Male Infertility - the End of an Era?” the authors claim that after the 1985 Act came into force access to donor sperm became starkly limited: "Our waiting times for treatment with donor insemination have lengthened and many couples have chosen to travel abroad, mostly to Denmark, for treatment" (Edvinsson et al. 1990, 1871). Another article in the same issue of the Läkartidningen enti- 
tled "Donor Insemination - a Treatment Method in Crisis" reports that before the 1985 Act approximately 200 donor-conceived children were born each year in Sweden. Yet during the four years immediately after the Act entered into force a grand total of 200 donor-conceived children were born (Hagenfeldt 1990, 1849). Bygdeman himself writes in a 1991 issue of Acta Obstetricia et Gynecologica Scandinavica that after donorconceived children "acquired the right to learn the identity of the donor, fewer couples are now seeking AID treatment, or else they seek it abroad; and since the anonymity of the donor is no longer protected, the recruitment of donors has become much more difficult” (Bygdeman 1991, 266). It seems that the lack of donor sperm has not subsided in Sweden. The National Board of Health and Welfare reported in 2004 that "there are still queues years long at clinics offering donor insemination” (Socialstyrelsen 2004, 17).

In an article co-written with Swedish infertility specialist Othon Lalos, Ken Daniels disputes the claim that the decline in donor insemination in Sweden resulted directly and exclusively from the 1985 Act. Instead, Daniels and Lalos attribute much of the decline to the line of action chosen by Swedish infertility doctors. Daniels and Lalos argue that the doctors were not happy to operate under the new legislation and were referring couples to other countries with the hope that the 1985 Act would fail. The authors write about an "exodus of patients to neighboring countries," particularly to Denmark and Finland (Daniels \& Lalos 1995, 1872). ${ }^{7}$ In addition, "as part of their protest (the doctors) did not seek to recruit donors, thus providing themselves with evidence to support their claim that the legislation would not work" (Daniels \& Lalos 1995, 1872).

It appears that Swedish infertility doctors did indeed find their way around the restrictions imposed by the 1985 Act. For example, Lars Hamberger is quoted in a 1996 publication as saying that after the enactment of the 1985 Act he informed his patients about a clinic in Copenhagen which offered anonymous donor insemination. And when the Act on In Vitro Fertilization was passed in 1988, Hamberger informed patients about a clinic in London offering treatment with donated eggs - a treatment method prohibited in the 1988 Act: "I have helped with addresses, wrote letters, and started hormone stimulations, but I haven't done the

\footnotetext{
${ }^{7}$ Daniels recounts that during a 1993 visit to "one of the largest clinics in Finland" he was told that $50 \%$ of the couples seeking donor insemination were from Sweden (Daniels 1994, 438).
} 
one thing that is expressly against the law, namely provided donor eggs" (see Nilsson 1996, 137).

Swedish infertility doctors' opposition to the donor-conceived child's right to receive identifying information about the donor may be reflected in the findings of a follow-up study of donor insemination in Sweden. According to the study, published in a 2000 issue of Human Reproduction, only $11 \%$ of parents had told their donor-conceived child about his or her origin (Gottlieb et al. 2000). An additional 41\% reported that they intended to tell and $48 \%$ said they would not tell. All the parents participating in the study had been "actively stimulated" to tell their prospective child about its biological origin. They had also been informed that the process of informing the child would be easiest if it were begun when the child was young and if increasing amounts of information were added as the child ages. Of the group of parents (89\%) who had not informed their child of their DI origin, 53\% had told someone else, thereby exposing their child to the risk of finding out from an outsider. However, as is reported in the study, the frequency of parents who had told their child increased from 6\% in the group of children born 1983-1986 - i.e. before the new legislation - to 18\% in the group born 1987-1990. This indicates that attitudes toward informing the child about donor insemination have changed over time (Gottlieb et al. 2000). Arguably because of the fact that such a small portion of donor-conceived children are told about their origins, only a few, if any, donor-conceived children have used the opportunity to get information about their biological father. As of February 2005, according to an infertility doctor working at the Karolinska Institute, the Institute had not received a single such inquiry.

Despite the persistent unhappiness of the Swedish infertility doctors with the 1985 Act, the Swedish government has been determined not to give in to the pressure. In November 1991 the Minister of Health and Social Affairs announced at a session of the Riksdag that there was no plan to change the legislation dealing with the donor-conceived child's right to access donor information (Daniels \& Lalos 1995, 1873).

In the meantime, in 1982 Hamberger's research group was successful in delivering the first Nordic test-tube baby at the Sahlgrenska Hospital in Gothenburg. After handing over its report on artificial insemination, the Insemination Committee continued to investigate "questions of an ethical, juridical, medical and psycho-social nature concerning fertilization out- 
side the body, in vitro fertilization, IVF and surrogate motherhood" (SOU $1985: 5,63$ ) with the task of making a proposal for legislation regarding in vitro fertilization.

The second report of the Insemination Committee, entitled "Children Through Fertilization Outside the Body” (SOU 1985:5) is dominated by a cautious attitude towards assisted reproduction. This caution manifests itself in a section dealing with the use of donated gametes in combination with IVF: "The Committee thinks a limit should be set to how far to go regarding manipulations to remedy childlessness" (SOU 1985:5, 66). According to the Committee, the use of donated sperm in and by itself is a step away from the natural process of procreation and therefore a cause of concern. The combination of sperm donation and IVF obviously entails an even greater distance from the natural order of things and the Committee felt compelled to set the limit there: "This method of fertilization should therefore not be allowed in Sweden" (SOU 1985:5, 66).

Egg donation was an issue that was only briefly touched upon in the 1983 report. However, in its second report the Insemination Committee provided a lengthy commentary on the subject. At the beginning of the report the Committee stated that "egg donation does not occur in Sweden" (SOU 1985:5, 9). Later on it becomes evident that the Committee did not wish to change the status quo. First, among the legal problems connected to egg donation was, according to the Committee, the problem as to who should be regarded as the mother of the child: the woman who donates the egg or the woman who gives birth to the child (SOU 1985:5, 45). Secondly, the Committee referred to problems of a psycho-social nature, i.e. "difficulties and conflicts" that egg donation would create in the family (SOU 1985:5, 46). Thirdly, the Committee considered that the medical problems of egg donation included an "uncertainty factor": How does an egg from one woman react when it is transferred to develop in another woman's body? Although clinical evidence on humans was scarce at the time, the Committee conceded that animal experiments indicate there were no negative outcomes to the offspring (SOU 1985:5, 46). Fourthly, because egg donation "goes completely against the natural process of life" and is a highly "technical construction," the Committee concluded that it would be unethical to allow it as a method to treat infertility (SOU 1985:5, 47-48). 
According to a Swedish legal expert, the members of the Insemination Committee were "reluctant to allow this kind of manipulation [i.e. infertility treatments] with the human life (...) With this in mind the Committee simply forbade everything that could be forbidden. Donor insemination could not be forbidden because it was a very simple technique, anyone can do it so they felt that in order to protect the children, the resulting children, it would be better to allow this and to make sure that as many as possible would turn to hospitals. But egg donation was something where you need the help of the medical profession and the prohibition would be effective. (...) But this was controversial and the question of allowing egg donation was simmering ever after the 1988 legislation when IVF was allowed. The manipulation of the beginning of human life was allowed so the reasons for not allowing egg donation were maybe not that strong."

Fairly soon after the introduction of the Act on In Vitro Fertilization (1988:711) the Swedish National Council of Medical Ethics started deliberating on the ethics of the different methods of assisted reproduction. Among the issues discussed was the question of egg donation. ${ }^{8}$ In its 1995 report “Assisted Fertilization” (Statens medicinsk-etiska råd 1995) to the Ministry of Health and Social Affairs, the Council noted that Swedish women were seeking treatment with donated eggs abroad, mainly in England and Italy. In the Council's opinion, egg donation should be permitted in Sweden for reasons of sex equality: since infertile men are allowed to become (social) fathers via donor insemination there is no reason why infertile women should be denied the opportunity of becoming mothers via the use of donated eggs. Furthermore, according to the Council, even though the woman in this case is not the genetic mother, she has gone through pregnancy and given birth to the child and is thus the biological mother of the child (Statens medicinsk-etiska råd 1995).

In addition, several administrative agencies and social organizations which had been invited to comment on the Council's report found the differential treatment of sperm donation and egg donation in Swedish legislation illogical and discriminatory. On the other hand, the Swedish Psychological Association wrote in its opinion that "the differences between egg donation and sperm donation are significant. Sperm always

\footnotetext{
${ }^{8}$ The Council had already in its 1987 statement on the Insemination Committee’s report "Children through Fertilization outside the Body" decided that egg donation and sperm donation are ethically and genetically comparable techniques, saying that "both egg and sperm are equally important for the becoming of a new individual” (see Ds 2000:51, 42).
} 
come from the outside but never before has a foreign egg been transferred into a woman's body" (Ds 2000:51, 39). In the government bill prepared by the Ministry of Health and Social Affairs (Prop. 2001/02:89), it was proposed that IVF treatment with donated eggs or with donated sperm be allowed. With the exception of the Christian Democratic Party, all parties were in favor of the bill and the Riksdag approved the bill in April 2002.

The revised legislation was to enter into force on January $1^{\text {st }} 2003$. The commencement of treatments, however, was delayed considerably because of orders issued by the National Board of Health and Welfare at the last minute, on December $20^{\text {th }}$ 2002, requiring that egg donors be tested for HIV. This created an uproar among infertility doctors and patients who were eager to start the treatments. In the resulting exchange an infertility doctor from the Karolinska Institute accused the Board of scientific incompetence and a lawyer representing the Board responded by pointing out that infertility treatment is not a prioritized area in health care (Folcker 2002). ${ }^{9}$

In early 2003 there was another bout of controversy over assisted reproduction in the Swedish media when the Dagens Nyheter published an opinion piece about reproductive cloning. The opinion piece, entitled “Cloned Children Ought to be Welcomed with Joy” (Tännsjö 2003), appeared soon after rumors started circulating in the world press about an upcoming birth of as many as two cloned babies - one claim brought about by an obscure religious group called the Raelians and the other by controversial Italian infertility doctor Severino Antinori. The opinion piece presented a philosophical justification for cloning as a method of assisted reproduction. The piece prompted a flurry of responses, most of

\footnotetext{
${ }^{9}$ In a 1995 report by the Swedish Parliamentary Priorities Commission, health care is divided into five priority groups, group I ("care of life-threatening acute diseases”) being of the highest priority and group V being of the lowest priority ("care for reasons other than disease or injury”). Infertility treatments were placed in group IV, the so-called "borderline cases," together with "hormonal treatment for shortness of stature due neither to hormonal nor any other disturbance and psychotherapy in cases where the existence of a mental disorder is doubtful" (SOU 1995:5, 27). In terms of funding, the Priorities Commission suggested with regard to group IV that "it is desirable that funding should be set aside for these purposes. If resources are insufficient, it is reasonable for the mandator [sic] to limit public expenditure on these measures, for example by limiting the number of treatment attempts for involuntary childlessness, tightening up the indications so that only childless couples will be treated, and/or raising the degree of cost coverage by the persons treated" (SOU 1995:5, 28).
} 
them highly critical of the idea of reproductive cloning. ${ }^{10}$ Human reproductive cloning was explicitly banned in Sweden in 2005 in connection with the revision of the 1991 Act Concerning Measures for Purposes of Research or Treatment Involving Human Ova (1991:115).

In March 2005 the Ministry of Justice announced that it would introduce a bill allowing lesbian couples to have access to assisted reproduction. The announcement took place a few years after a much discussed legal case in Sweden in which a lesbian mother separated from her partner sought and won financial support for her three children from the sperm donor (Helsingin Sanomat 5.2.2002). The government bill (Prop. 2004/05:137) was based on a report by a parliamentary Committee on Children in Homosexual Families appointed in February 1999. The Committee's mandate was two-fold: first, it was to investigate the situation of children living in homosexual families. Secondly, it was to examine the legal differences between homosexual and heterosexual couples with regard to adoption. If it came to the conclusion that such differences existed and were not "factually motivated" (Dir 1999:5), the Committee was to suggest changes to remedy the situation and, furthermore, to consider whether lesbian couples should have access to assisted reproduction (SOU 2001:10, 463).

The Committee handed over its report "Children in Homosexual Families” in January 2001. The Committee concluded, first, that registered homosexual couples can offer an adoptive child a good environment for its upbringing and can fulfill such child's special needs. In view of this, the Committee proposed that homosexual adults registered in a legal partnership be entitled to apply for adoption and that any general impediment to such adoption should be removed (Ministry of Justice 2003).

This portion of the report led to the introduction of the government bill on Partnership and Adoption (Prop. 2001/02:123) to the Riksdag in March 2002. The Riksdag approved the bill three months later, in June 2002. Under the newly amended act, which came into force in February 2003, gay and lesbian couples in a registered partnership have the same rights as married couples to apply to become adoptive parents. In addi-

\footnotetext{
${ }^{10}$ The titles illustrate well the general drift of the responses: "Satsa på människor som redan finns”; "Samma gamla Nazism”; ”Dolly är sjuk, kanske död”; ”Tiotusen gånger Schwartzenegger” and "Cynisk spel med människoliv" (www.dn.se/DNet/jsp/polopoly.jsp?d= 93616\& forummode=show 13.9.2005).
} 
tion, one partner can adopt the other partner's child, whether the child is the biological or adoptive child of the other partner.

The Committee on Children in Homosexual Families proposed, secondly, that lesbian couples should be allowed to have access to assisted reproduction. To ensure the child's right to two parents the Committee suggested that the biological mother's registered partner should automatically be regarded as the second parent of the child. If the couple was not living in a registered partnership, the cohabitant's parenthood should be established either by acknowledgement or in court. These rules are similar to the rules regarding the establishment of paternity in a heterosexual couple. However, the Committee acknowledged that sperm donation may open up the sole avenue to fatherhood for gay men. The Committee suggested, accordingly, that the paternity of the sperm donor can be established under the condition that the biological mother has consented to it (SOU 2001:10, 24).

Several agencies and organizations that had been invited to comment on the report pointed out that the proposed limits on the possibilities to establish paternity were too stringent and could have an adverse effect on the child's right to access information on the biological father as well as the child's opportunity to contact the father. Alternative solutions for lesbian couples to become parents were suggested, such as stepchild adoption (Ds 2004:19, 35-36).

Preparatory work was continued at the Ministry of Justice resulting in a government bill entitled "Assisted Fertilization and Parenthood" (Prop. 2004/05:137). In the bill it is proposed that the Insemination Act of 1985 and the Act on In Vitro Fertilization of 1988 applied also to situations where a woman lives with another woman either in a registered partnership or as a cohabitant. According to the bill, the partner or cohabitant of the biological mother will be regarded as a parent of the child on condition that she has consented to the treatment and it is 'likely' that the child was conceived via assisted reproduction. The partner's or cohabitant's parenthood has to be established either by acknowledgement or in court in order to become legally binding. This arrangement will apply only to children who are born within the Swedish health care system. If the child is born outside the Swedish health care system, i.e. abroad or as a result of an at-home insemination, the partner or cohabitant of the mother will 
have to adopt the child in order to become a legal parent. The amendments entered into force in July 2005.

The gradual liberalization of ART legislation in Sweden has left only one obvious group of potential beneficiaries without access to assisted reproduction, namely single women. This fact appears not to have elicited objections from the country's feminist movement. The visibility of the Swedish Association for Sexual Equality in advocating for the access of lesbian couples to assisted reproduction has been matched with silence from the feminist movement with regard to access for single women.

Teresa Kulawik observes the same fact, although from a different angle. She points out that "(s)everal new procedures require that human egg cells be available, a demand that can only be met through intrusive treatments for women's bodies” (Kulawik 2004, 1). In the context of a nation with well-established traditions of women-friendly policies, "it might be assumed that women involved in policy-making would problematize the gendered implications of biomedical techniques that turn women into suppliers of human 'raw materials'” (Kulawik 2004, 4). This notwithstanding, "gendered consequences of biomedical techniques have hardly even been mentioned in Swedish political discourse” (Kulawik 2004, 4).

Only the Christian Democratic Party has provided a constant oppositional force in the otherwise consensual politics of assisted reproduction in Sweden. The Party program (Kristdemokraterna 2001) speaks about human dignity, människovärdet, which it states is tied to the simple fact of human existence and "not to the different stages and situations in an individual's life cycle” (Kristdemokraterna 2001, 4). The program commits the Christian Democrats to be guided by the principle of human dignity in their politics in general. However, the principle of human dignity appears to supply a particularly appropriate framework for the politics of biomedicine. The Party program explicitly states that each and every person's absolute, unique, and inalienable dignity shall inform the rules and practices of medical ethics (Kristdemokraterna 2001, 25). As a matter of parliamentary politics, the Christian Democratic Party has sought to promote human dignity through parliamentary motions, unsuccessful thus far, to amend the Swedish law with a constitutionally guaranteed right to life. ${ }^{11}$

\footnotetext{
${ }^{11}$ In a statement on medical ethics in 1998, the Christian Democrats propose a constitutional amendment on the right to life: "Vi kristdemokrater anser att den mest grundläggande mänskliga
} 
A second principle that informs the Christian Democratic thinking and activities in the domain of biomedicine is the principle of caution: "Our main priority is to have the rule of caution, försiktighetsprincipen, implemented into Swedish legislation when it comes to bioethics: not to implement new laws or make new laws without having this very, very cautious attitude toward dealing with human life.” For instance, the Party's statement on medical ethics (Kristdemokraterna 1998) suggests that assisted reproduction should follow the natural process of procreation as closely as possible to avoid ethical and legal problems that, according to Christian Democrats, result from technological manipulation of human reproduction.

Finally, the Christian Democratic stance on assisted reproduction and biomedical research follows from the belief that God regards each human life as precious and valuable from the moment of conception. The respect for the human life from its very beginning determines the Christian Democratic position on biomedical research in a profound way, as testified by an MP from the Christian Democratic Party: "You could use organs from fetuses and you could use stem cells from early embryonic stem cells and say that these are not human beings, these are just human organic garbage, but Christian Democrats would all agree that this could never be the case - that you could define a living human being as garbage, as human garbage. This is a human being with its own right to legal rights."

Possibly in an effort to insulate themselves against such charges, governmental committees in Sweden have developed a linguistic strategy of avoiding the term "embryo" and using the term "fertilized egg" instead. ${ }^{12}$ Teresa Kulawik notes that while this "politics of language" (Kulawik 2004, 17) can be traced back to the 1980s, the Committee on Genetic Integrity in particular "put much effort in addressing questions of language” (Kulawik 2004, 21). In its report "Legal Regulation of Stem Cell Research" (SOU 2002:119) the Committee stated, for instance, that "because language has a certain power to influence thought, the term embryo

rättigheten, rätten till liv, bör ingå i regeringsformens värdeorientering i målsättningsstadgandena. (...) Vi föreslår följande tillägg: Den offentliga makten skall utövas med respekt för människolivets okränkbarhet, alla människors lika värde och för den enskilda människans frihet och värdighet” (Kristdemokraterna 1998).

${ }^{12}$ Note, also, the Act Concerning Measures for Purposes of Research or Treatment Involving Human Ova (1991:115). 
should be used with caution. The term fertilized egg is the most suitable term to describe the phase directly following fertilization" (SOU 2002:119, 65). Kulawik considers this as a discursive strategy to pave the way for such applications of biomedicine as therapeutic cloning and the production of embryos solely for research purposes that are perceived as ethically problematic in many parts of the world. Furthermore, since the Convention on Human Rights and Biomedicine prohibits the creation of human embryos for research purposes, the linguistic strategy deployed by the Committee on Genetic Integrity is, according to Kulawik, also a way to circumvent the Convention without directly contradicting it ${ }^{13}$ (Kulawik 2004, 21).

Of course, such strategies make sense for a nation, which competes aggressively, and successfully, in the international market of biotechnology. Sweden's success in stem cell research has earned it a place among the "innovator countries" (Rothmayr et al. 2004, 246), the leading performers in biotechnological research. This position requires a regulatory environment favorable to the innovation capacity and commercialization of biotechnology. It appears that the ART policy design in Sweden reflects some aspects of the general priority setting in biotechnology.

Although ethical considerations have been present throughout the Swedish ART policy design process, it has been driven by experts and bureaucrats. This type of design process, designing by experts (Rothmayr et al. 2004, 251), has allowed only a limited space for citizen participation (Häyrinen-Alestalo \& Kallerud 2004, 15) and for the mobilization of extra-parliamentary groups (Kulawik 2004, 4).

\footnotetext{
${ }^{13}$ In fact, the Committee on Genetic Integrity proposed that "Sweden should express its reservations with respect to article 18.2” (see Kulawik 2004, 21).
} 


\section{Norway}

Norway has been characterized as "an early legislator and a strict regulator" (Bleiklie 2004, 209) in the domain of assisted reproduction. The Norwegian Act on Artificial Fertilization (68/1987) was the first Nordic law to cover the entire field of assisted reproduction. Its enactment took place in the midst of a political struggle over abortion. The 1987 Act came to articulate a variety of concerns with ART ranging from the need for the protection of unborn human life to the avoidance of risk to health. These concerns have continued to dominate Norwegian ART policies through a number of legislative actions over the years. Each of the three separate Acts passed so far has started with a preamble laying down the ethical foundation for the subsequent restrictions. The most recent piece of legislation, the Act on the Medical Use of Biotechnology (100/2003), opens with the following statement: "The purpose of this Act is to ensure that medical applications of biotechnology are utilized for the benefit of everyone in an inclusive society. This shall be done in accordance with the principles of respect for human dignity, human rights and personal integrity and without discrimination on the basis of genetic constitution, on the basis of the ethical norms that form part of our Western cultural heritage.”

The debate around assisted reproduction has offered the Christian Democratic Party - the staunchest opponent of the 1978 liberalization of the abortion law - an opportunity to reclaim a strong moral standing with respect to human dignity in general and unborn human life in particular. By all accounts, the Christian Democrats have been tremendously successful in seizing the key political role in the Norwegian ART policy design process. Their success is due, in large part, to a phenomenon that has characterized the Norwegian parliamentary democracy from the 1970s on - the prevalence of minority governments: "A recurrent feature of this situation has been that most minority governments have come to depend on the support, participation or leadership of the Christian Democrats in order to survive. Thus, through shifting configurations of party alliances, this party has been able to ensure that its core issues remain at the centre of the political agenda” (Kallerud 2004, 86).

The country's strict ART legislation has left its infertility doctors with a minimal amount of professional autonomy, a fact which has been received with varying degrees of resentment by the doctors. In November 2004, Nor- 
wegian infertility specialists founded an association, the Norwegian Society for Assisted Reproduction (NOFAB), as part of an effort to strengthen their bargaining position in the politics of assisted reproduction.

In 1985, one year after the birth of the first Norwegian test-tube baby in 1984 at St. Olavs Hospital in Trondheim, the Parliamentary Committee of Health and Social Affairs requested that the government prepare a proposal for legislation on artificial insemination and in vitro fertilization. The initiative resulted in the enactment of the Act on Artificial Fertilization in 1987. The Act on Artificial Fertilization laid down a number of restrictions and prohibitions on assisted reproduction including a ban on egg and embryo donation, embryo research, and the freezing of eggs; the restriction of assisted reproduction to married couples; and the requirement that IVF be performed only with the couple's own gametes. Even so, the Christian Democrats and the Center Party voted against the bill, claiming that it was too permissive (Bleiklie 2004, 215-216).

During its debate on the 1987 Act the Storting requested that the government present a report to the Storting on ethical guidelines for research and development in biotechnology. At that point, according to Torben Hviid Nielsen, "ethics and morality became code and arena for the debate on IVF and medical uses of biotechnology" (Hviid Nielsen, cited in Kallerud 2004, 87).

The request by the Storting led to the establishment of two committees to prepare the political process for establishing a regulatory framework for biotechnology. The Biotechnology Committee was established in June 1987, primarily to address environmental and health issues related to the use of modern biotechnology. The Ethics Committee, appointed in April 1988, would investigate the medical applications and the human aspects of biotechnology. ${ }^{14}$

The report of the Ethics Committee, "On Humans and Biotechnology" (NOU 1991:6), was published in November 1990. As required by its mandate, the Committee identified a number of ethical principles, both in the Christian and in the humanistic tradition, as guidelines to be followed

\footnotetext{
${ }^{14}$ Egil Kallerud mentions that "this bifurcation of the process was later built into the regulatory framework in the passing of two separate acts," namely the Act Relating to the Production and Use of Genetically Modified Organisms (the Gene Technology Act 38/1993) and the Act Relating to the Application of Biotechnology in Medicine (the Biotechnology Act 56/1994) (Kallerud 2004, 87-88; see also Bleiklie 2004, 216).
} 
in biotechnological decision-making. The Committee discussed a wide range of biomedical applications such as assisted reproduction, embryo research, DNA technology, genetic testing, and gene therapy, but came up with only two unanimous recommendations: one setting human dignity as a legislative goal and another banning embryo research (Ot.prp. nr. 64: 2002-2003, 17).

The report by the Ethics Committee served as a basis for the government report to the Storting in March 1993. The report by the Labor government attempted to ease the strict regulations of the 1987 Act, but was rejected by the Storting. Nonetheless, the resulting legislation, i.e. the Act Relating to the Application of Biotechnology in Medicine (the Biotechnology Act 56/1994), represented "a careful step in a more permissive direction” (Bleiklie 2004, 217). Maximum storage time for embryos was extended from 12 months to three years, indications for IVF treatment were expanded to include male and unexplained infertility, and preimplantation diagnosis was now permitted under certain conditions. ${ }^{15}$

In June 1989, four members of the Christian Democratic Party made a proposal to the Storting regarding the regulation of gene technology. The proposal led to the establishment of the Norwegian Biotechnology Advisory Board in 1991. The Norwegian Biotechnology Board is the key institution in the Norwegian government structure for biotechnology (Kallerud 2004, 88). Its task is to evaluate the social and ethical consequences of modern biotechnology and to discuss usage promoting sustainable development. ${ }^{16}$ The members of the Board are appointed by the government. Because of this and several other formal links to the government request for advice, civil servants as members and observers, etc. - the independence of the Board has been subject to some criticism. This criticism increased after the "unabashedly" political appointment of members of the Board by the Labor government in 2000 as well as by the centerright government in 2002 (Kallerud 2004, 90).

In the context of the passing of the 1994 Biotechnology Act, the Storting required the Act to be evaluated after a period of five years (Innst.O. nr. 67: 1993-1994, 21). The evaluation was to be undertaken jointly by

\footnotetext{
${ }^{15}$ The use of PGD, however, was only a theoretical option since embryo research was still prohibited.

${ }^{16}$ www.bion.no/index_engl.shtml 19.9.2005.
} 
the Biotechnology Board, the Ministry of Health, and the Norwegian Board of Health. ${ }^{17}$

While the evaluation process was taking place, several revisions were made to the 1994 Act. When the Labor Party took over the government in March 2000, it was generally expected that some degree of liberalization would take place (Bleiklie 2004, 218). However, this did not happen. In fact, one of the major changes to the 1994 Act actually made the law even more restrictive since the Storting approved a proposal in December 2000 to have the infertile couples themselves pay the costs of infertility treatment. However, only six months later, after intensive lobbying by the Norwegian infertility association the government was forced to compromise and the national health insurance assumed part of the costs. ${ }^{18}$

The result of the evaluation process, a report by the Ministry of Health (St.meld. nr. 14: 2001-2002), was introduced to the Storting in March 2002. In accordance with what had become a Norwegian tradition in the domain of biomedicine, the evaluation paper first situated the subsequent discussions and recommendations in the context of ethics and morality. Human dignity, in particular, was emphasized as a normative foundation for reflections regarding biotechnology. Human dignity was defined as "a value in and by itself” (Ot.prp. nr. 64: 2002-2003, 15) whereby human life should never be used as a means by other human beings. In Norwegian society, according to the report, most people regard the right to life as the highest good and, accordingly, the single most important aspect of human dignity. Therefore in its protection of life through diagnostics and treatment of diseases, biotechnology is broadly accepted, stated the report (Ot.prp. nr. 64: 2002-2003, 15).

Another fundamental value considered by the Ministry of Health was autonomy. The Ministry's view on autonomy was cautious, however, because "the realization of individual autonomy may take its toll on so-

\footnotetext{
${ }^{17}$ After a 2002 reorganization of the central administration in the area of social affairs and health, the management of biotechnology is shared by the Ministry of Health, the Directorate of Social Affairs and Health, and the Norwegian Biotechnology Advisory Board.

${ }^{18}$ Currently the couples pay 18.000 NOK for a package, which consists of a maximum of three treatment cycles in public hospitals. All expenses beyond that amount are covered by the national health insurance.
} 
cietal needs and the integrity of others.” In this context the Ministry also emphasized that unborn human beings have a moral status in society. ${ }^{19}$

Of the proposed changes to the previous law, the most important one was the abolishment of donor anonymity. It was decided that the donorconceived child's right to access donor information is necessitated by the Convention on the Rights of the Child. The Convention entered into force in 1990 and was ratified by Norway in 1991. According to Article 7.1. of the Convention, "the child shall have (...) as far as possible, the right to know and be cared for by his or her parents."

The abolishment of donor anonymity was opposed by several agencies and organizations that had been invited to comment on the proposal. The Norwegian Medical Association, which had otherwise stood clear of the debate, opposed the proposal claiming that it would "create unnecessary problems and conflicts for the child, for the biological father, and for the social father." 20

According to the new Biotechnology Act, i.e. the Act on the Medical Use of Biotechnology (100/2003), a child born as a result of medically assisted reproduction using donated sperm has a right to information on the donor's identity at the age of eighteen. The new stipulation meant a significant change in the practice of donor insemination in Norway because, prior its entry into force, all donor sperm was imported from Denmark where donor anonymity is guaranteed by law. In September 2004 the Directorate of Social Affairs and Health launched a campaign in order to recruit a pool of Norwegian sperm donors. ${ }^{21}$ Such campaigns had failed in the past, and there was concern in the medical community that donor insemination would have to be discontinued because of the lack of donor sperm. This time, however, the efforts were directed at men who already had children of their own, as opposed to the previous efforts which had focused on the university student population, and the results seem to have been successful enough to satisfy the need for donor sperm for a year or two. However, according to an infertility doctor working at a

\footnotetext{
19 "Etter departementets syn må det i bioteknologisammenheng være et grunnleggende prinsipp at det ikke kan foretas et kvalitetsmessig skille mellom ufødte og fødte” (Ot.prp. nr. 64: 2002-2003, 15).

${ }^{20}$ However, a sizeable minority of the members of the Association was in favor of the abolishment of donor anonymity (Ot.prp. nr. 64: 2002-2003, 42).

${ }^{21}$ In addition to a press campaign, pamphlets were distributed in hospitals and pharmacies. “Ikke alle får barn selv om de ønsker det. Vil du hjelpe?” (www.rikshospitalet.no/saedgiver 15.5.2005).
} 
public hospital, donors recruited since September 2004 are exclusively of Caucasian origins: "It's very difficult to recruit ethnic donors. We have a lot of patients from Pakistan and other countries. We will probably not be able to offer them treatment in the future unless they are willing to accept Caucasian donors.”

In addition, the provisions on pre-implantation genetic diagnosis (PGD) were revised. The 1994 Act allowed PGD to detect "an incurable hereditary disease with no possibility of treatment" (Section 4-2). In the 2003 Act, PGD is restricted to "serious sex-linked hereditary diseases for which no treatment is available" (Section 2-14-1).

According to infertility specialists, the restriction to sex-linked hereditary diseases is based on a misunderstanding of the relevant scientific facts. ${ }^{22}$ The significance of sex in this context is usually associated with sex selection: whenever there is a known risk of sons being affected by serious genetic disease, female embryos may be selected using PGD. The revision elicited a disapproving comment from a scientist working in the field of assisted reproduction: "So if you are sick because your gene resides from the $\mathrm{x}$-chromosome that's all right, but if it comes from chromosome 17 you can forget it. That makes absolutely no sense.”

The full impact of the revision became apparent soon after the 2003 Act had been passed by the Storting. In spring 2004 Norwegian media was buzzing over Mehmet-saken, ${ }^{23}$ a case involving 6-year old boy of Turkish origin, who suffered from beta thalassemia major, a genetic blood disorder. ${ }^{24}$ In order to provide a cure for their son, Mehmet's parents had a plan to conceive a healthy baby so that its bone marrow could be transplanted to Mehmet. However, while thalassemia is a serious hereditary disease, it is not sex-linked. Even if Mehmet's parents succeeded in creating an embryo by IVF, screening it for thalassemia would be prohibited by the new Act. In the wake of public sympathy for the family, the opposition parties were ready to change the brand-new Biotechnology Act but were unable to convince Kjell Magne Bondevik's government, a

\footnotetext{
${ }^{22}$ Two Nordic infertility doctors, Johan Hazekamp (Norway) and Lars Hamberger (Sweden) call the revision "an excellent example of the dilemma related to legislation based on party politics rather than sound science (...)” (Hazekamp \& Hamberger 2005).

${ }^{23}$ For Mehmet-saken see, e.g., Innst.O.nr.71 (2003-2004), Sosial- og helsedirektoratet 2004, Straumsheim Grønli 2004, Skogstrøm 2004, Helsedepartementet 2004a.

${ }^{24}$ This particular type of thalassemia is a life-threatening anemia that requires regular, lifelong blood transfusions. These blood transfusions lead to iron-overload, a condition which must be treated with chelation therapy to prevent early death from organ failure.
} 
minority coalition of the Conservatives, the Christian Democrats, and the Liberals, to take action.

The opposition was eventually successful in forcing the majority to amend the law in the Storting (Besl.O.nr.78: 2003-2004). In June 2004 the Storting added an exemptions clause to the 2003 Act, which stipulates that "if special considerations so indicate, the exemptions board (...) may grant permission for genetic testing of embryos. Such permission may be granted for serious hereditary diseases for which no treatment is available” (Section 2-14-2). The revision came into force in September 2004. In December 2004 the Dispensation and Appeals Board for Treatment Abroad $^{25}$ made a decision to allow Mehmet's family to seek treatment for their son abroad at the state's expense (Aftenposten 10.12.2004, Dagbladet 10.12.2004).

In the political configurations of biotechnology in Norway, the Christian Democratic Party has been, for the most part, supported by the Center Party and the Liberal Party to form the core of the 'technology pessimist' political alliance. Technology pessimists are, according to Ivar Bleiklie, "restrictive with regard to regulation issues, and prefer to introduce legislation that pre-empts technological development. The pessimists share a belief in the potential dangers of scientific activity if democratic institutions do not control it” (Bleiklie 2004, 221).

The opposite side of the political division line features the Labor Party and the Conservative Party - the latter one, however, only intermittently and uneasily because of its general commitment to traditional family values. These two parties make up the 'technology optimist' alliance that "takes a liberal stand on regulation issues, and prefers to introduce legislation after or in step with the technological development in the field" (Bleiklie 2004, 221). In general, they have not been able to contribute substantially to the ART policy design in the country "because of party politics and an interest in not endangering the minority government” (Rothmayr et al. 2004, 237).

\footnotetext{
${ }^{25}$ The Dispensation and Appeals Board for Treatment Abroad decides whether patients may seek medical treatment abroad at the state's expense in cases where no adequate treatment is available in Norway. With three added members, the Board also acts as the exemptions board, mentioned in Section 2-14-2 of the 2003 Act, which may grant permissions for genetic testing of embryos in cases of "serious hereditary disease," i.e. other than sex-linked hereditary disease (Helsedepartementet 2004b).
} 
One of the target groups of the policy design, the infertility doctors, have found themselves on the losing side along with the technology optimists. There appears to be a whole host of factors explaining the limited influence of the medical community on the policy design. First, the medical community itself is divided on the issue of assisted reproduction. According to Bleiklie, "research in this field has been concentrated mainly in one university (which) suggests that this research may have had a rather narrow base of support within the medical community" (Bleiklie 2004, 223). One of the interviewees from the ART research community confirmed this view saying that "I guess if there was a vote at the hospital between the doctors we would be voted out."

Secondly, the policy design process in Norway can be characterized as design by party politics, i.e., design dominated by politicians and legislative activity (Bleiklie 2004, 223; Rothmayr et al. 2004, 251). The shift away from an earlier type of design process, design by experts, took place in Norway in the 1980s. The drafting of the first piece of ART legislation, the 1987 Act, still exhibited some of the elements of this earlier design type, as verified by a scientist working in the field: "(The 1987 Act) was inspired by some of the (ART) pioneers who had good political contacts." But as Bleiklie points out, "the movement of an issue from one institutionalized arena to another brings it together with a new set of actors that may define the problem and its solutions in new and unexpected ways" (Bleiklie 2004, 223). Once the shift took place in Norway it removed the physicians from their earlier position of political influence. The establishment of NOFAB (the Norwegian Society for Assisted Reproduction) in November 2004 was part of an attempt to address the problem of diminishing political clout. 26

The restrictive ART policy design in Norway has, according to Norwegian infertility doctors, proven detrimental to the provision and development of assisted reproduction in the country. Infertility doctors claim that Norway started in vitro fertilization on par with the other Nordic countries in the 1980s but has now fallen years behind. Since embryo research is categorically prohibited, "including simple methodological research” as Hazekamp and Hamberger point out, Norway is in effect

\footnotetext{
${ }^{26}$ NOFAB's press release in November 2004 stated that "foreningen skal virke some profesjonenes talerør overfor myndighetene og befolkningen i politiske, faglige og etiske spørsmål som vedrører ufrivillig barnløshet” (www.legeforeningen.no/index.gan?id=53533 16.5.2005).
} 
"totally dependent on other countries for simple developments in embryo culture and handling techniques” (Hazekamp \& Hamberger 2005). This reliance on research conducted in other countries has not only delayed the adoption of newer, safer, and more efficient treatment methods but it has also given rise to accusations of double standards. A Norwegian scientist working in the field of ART recalled that when Norway allowed ICSI in 1994, "all the clinics starting up with ICSI needed a license. To have a license we needed to demonstrate knowledge and skill. To have this knowledge and skill, we had to go somewhere to train. So we had to document that we had been training on Swedish and Belgian women's oocytes, which was strictly forbidden in Norway, but we had to document that we had done it. And then it was all right."

Because of the ban on embryo research, Norway is the only Nordic country, apart from Iceland, that does not allow stem cell research, a fact which makes Hazekamp and Hamberger to lament that "(n)ot only does this prohibit development in an important and exciting field of medicine, but it also excludes Norway from the scientific arena where decisions are made on the direction and uses of such scientific developments" (Hazekamp \& Hamberger 2005).

The medical community's criticism appears to have met with some success. In June 2005 the Storting instructed the government to introduce an amendment to the Biotechnology Act, which would allow for a limited use of PGD and embryo research (Vedtak 443/2005). 



\section{Iceland}

Iceland presents us with the least complicated case of ART policies among the Nordic countries. The Act on Artificial Fertilization (55/1996) was enacted in 1996 after relatively uneventful proceedings in Iceland's parliament, Alpingi. There has not been a single amendment to the Act during the almost decade it has been in force. Nor do the officials at the Ministry of Health and Social Security expect any changes in the near future. However, since the Act on Artificial Fertilization bans research on embryos, current developments in embryonic stem cell research have brought along pressures for change. Guðmundur Arason and borður Óskarsson, two infertility doctors in charge of the entire field of ART in Iceland, have by all accounts been tremendously successful in their clinical work. Their work has helped to create a positive atmosphere around ART in the country. This aura of acceptance may now be facing its first challenge with the opening of a private clinic by Arason and Óskarsson in November 2004. Critics of privatization have questioned the wisdom of removing infertility treatment from the auspices of the Landspítali, the University Hospital in Reykjavik. Among other things, the critics fear that privatization of infertility care will have a detrimental impact on teaching and research in the field.

The debate on assisted reproduction has been distinctively calm and consensual in Iceland. Whether it is the impeccable work of the country's two infertility doctors or the fact that no Christian Democratic party exists in Iceland to question the ethical ramifications of assisted reproduction, the fact remains that the ART policy design process took place in an air of mutual agreement. "There was relatively little debate except that everyone was in favor of implementing legislation allowing ART," said a health policy expert.

In vitro fertilization did not become available in Iceland until the early 1990s. Until then, infertile Icelandic couples traveled abroad for IVF treatments. By 1987 the volume of these trips had become so high that on 
May $15^{\text {th }}$ of that year Ragnhildur Helgadóttir, the Minister of Health and Social Security, issued a regulation ${ }^{27}$ providing for the State Social Security Institute (SSI) ${ }^{28}$ to cover the costs of the treatment if 1) the couple was married, 2) the treatment was necessary for medical reasons, and 3) only the couple's own gametes would be used in the treatment. The regulation was to apply retroactively to treatment cycles that had been commenced after June 1, 1986.

Since most Icelandic couples traveled to the Bourn Hall Clinic in Cambridge, UK for IVF treatments, SSI and the Bourn Hall Clinic entered into an agreement in January 1988, whereby SSI would cover the costs of the treatment if 1) the couple was married or had been living together for at least two years and 2) the woman was at most 38 years of age. In addition, childless couples had priority over those who already had children. The national health insurance covered only the costs of the treatment; the costs of travel, accommodation, and interpretation were left for the couple to pay. The choice of clinics for the Icelandic couples was not limited to the Bourn Hall Clinic. However, in case they did choose another clinic, the compensation paid to them by SSI was not to exceed the amount they would have received had they chosen the Bourn Hall Clinic. ${ }^{29}$

On March $25^{\text {th }} 1986$ the Alpingi adopted a resolution urging the government to set up a committee to investigate issues relating to ART. Since the investigation was to focus on the legal rights and obligations of the various parties involved in ART, in particular the rights of the child, the task fell under the domain of the Ministry of Justice and Ecclesiastical Affairs (from here on: the Ministry of Justice). Consequently, on July $28^{\text {th }}$ 1986, the Minister of Justice appointed Ólaf W. Stefánsson, a department chief from the Ministry of Justice, to head the Committee. The four other members included one representative from the Faculty of Medicine, one from the Child Protection Agency, and two from the Icelandic Lawyers'

\footnotetext{
${ }^{27}$ Reglugerð nr. 218/1987 um greiðslu læknishjálpar við glasafrjóvgun erlendis. - The costs of any medical treatment not available in Iceland are covered by the national health insurance. Reimbursement of medical treatment abroad is decided by the Siglinganefnd (literally: sailing committee) at SSI.

${ }^{28}$ The State Social Security Institute administers social insurance, including the payment of costs due to childbirth and child maintenance. The part of social insurance administered by SSI is divided into three sections: pension insurance, health insurance, and occupational injury insurance (www.tr.is 6.7.2005).

${ }^{29}$ Reglugerð nr. 218/1987 um greiðslu læknishjálpar við glasafrjóvgun erlendis.
} 
Association (Frumvarp til laga um tæknifrjóvgun 184/1995, 4). At the beginning of its mandate the Committee worked to collect material and information, only to soon fall into a state of inactivity that was to last for several years. The lengthy period of inactivity was at least partly due to the reluctance from the part of the Committee to legislate a field that was in a rapid state of development or, as pointed out by an Icelandic legal expert, "nobody really wanted to fix anything to be then stuck with something that would take ages to change."

In 1989 the government presented a budget proposal to the Alpingi that included an allocation for infertility treatments at an IVF unit to be created at the Landspítali the following year. Taken aback by the fact that these measures had been included in the budget proposal with no prior public debate and without any ART legislation in force, a group of parliamentarians led by Sigriður Lillý Baldursdóttir, an MP representing the Women's Alliance ${ }^{30}$, made an initiative for a parliamentary resolution on the $20^{\text {th }}$ of November 1989 calling for the drafting of a bill on assisted reproduction ${ }^{31}$ before creating an IVF unit at the Landspítali.

In her speech in the Alpingi, Baldursdóttir emphasized the risks of all technologies and called into attention the ethical aspects of assisted reproduction: "All technologies and science can be abused. The society is not always equipped to respond to the progress of science which, at times, requires totally new thinking and leaves us with a completely altered world view. For a long time technology set the limits for itself but this is not enough anymore. We have many examples: environmental damage, pollution, eradication of natural resources, deadly weapons invented by monstrous ingenuity - all these are products of scientific and technical development. Technical development in medicine has in many cases contributed to longer life of higher quality. It has also permitted many people the joy of having children of their own. We must make sure that the happiness of these people and their children will not be any less than the happiness of those how have had their children conceived the natural way. We must also be aware of the risks associated with this new tech-

\footnotetext{
${ }^{30}$ The Women's Alliance received three MPs in the 1983 election and retained representatives in the Alpingi until 1999 when it merged in a new left-wing party, the Social Democratic Alliance.

31 Tillaga til pingsályktunar um tæknifrjóvganir. Flm. Sigriður Lillý Baldursdóttir et al. 112. löggjafarping 1989. www.althingi.is/altext/112/s/0157.html 10.10.2005.
} 
nology and be determinate in preventing its abuse. Once again technology confronts us and requires us to set ethical limits." ${ }_{22}$

The proposed resolution was referred to the Social Affairs Committee where the reference to the IVF unit was omitted. In consequence, parliamentary resolution no. 318, adopted on the $14^{\text {th }}$ of December 1989 , simply urged the government to present a bill on artificial fertilization to the Alpingi as soon as possible. ${ }^{33}$ The IVF unit at the department of gynecology and obstetrics was opened at the Landspítali in 1990 and IVF treatments commenced at the unit in October 1991 with no ART bill presented to the Alpingi.

The absence of legislation did not mean that infertility treatment at the IVF unit took place in a regulatory vacuum. The Board of the University Hospital had issued a set of rules, which were approved by the Ministry of Health and Social Security in early 1992. According to these rules 1) the couple had to be married or have been living together in a stable relationship for at least three years, 2) the woman had to be at most 42 years of age, 3) only the couple's own gametes could be used in the treatment, and 4) the freezing of embryos was not permitted. If the couple already had children together, they were not eligible for treatment. Later on, at the request of the IVF unit, the Ministry of Health and Social Security decided to permit the use of donated sperm, with it giving permission in each case (Frumvarp til laga um tæknifrjóvgun 184/1995, 6).

On May $22^{\text {nd }} 1992$ an amendment to the Child Act clarified the situation regarding the paternity of children born as a result of the use of ART. According to the amendment, the man who had consented to artificial insemination or to in vitro fertilization was to be considered the legal father of the child. ${ }^{34}$

In September 1992 the Minister of Health and Social Security appointed department chief Dögg Pálsdóttir as a representative from the

\footnotetext{
${ }^{32}$ This is an excerpt of Baldursdóttir's speech, translated by Ingileif Jónsdóttir.

${ }^{33}$ pingsályktun um tæknifrjóvganir (318). Afgreidd frá Sp. 14. des. 112. löggjafarbing 1989. www.althingi.is/altext/112/s/0318.html 14.2.2005.

${ }^{34}$ The Act in Respect of Children (76/2003) includes two articles relating to children born as a result of the use of ART: Article 5 regarding maternity of children conceived by artificial insemination: "A woman who bears a child conceived by artificial insemination is deemed to be its mother" and Article 6, Paragraph 1, regarding paternity: "A man who has agreed that his wife be artificially inseminated according to the Act is deemed to be the father of a child so conceived. The same applies to a man and a woman who have registered their cohabitation with the National Registry.”
} 
Ministry to the ART Committee (Frumvarp til laga um tæknifrjóvgun 184/1995, 4). While both the parliamentary resolution of 1989 and the commencement of IVF treatments in the country had built pressure on the ART Committee to resume its work, it was apparently this new addition to the Committee, which finally brought its years of inactivity to an end. Three years later, in 1995, the Committee completed its work and the Minister of Health and Social Security submitted a bill on artificial fertilization to the Alpingi.

The bill did not cause a whole lot of debate in the Icelandic Parliament. There was a general consensus that it was necessary to implement legislation on assisted reproduction. "Everybody was very happy about it," said a health policy expert. Consensus on prohibiting such controversial methods as cloning and surrogacy also evolved fairly quickly. The most controversial article of the bill was Article 4 regarding donor anonymity. The bill proposed total anonymity - the donor was not to be given any information on the recipients or the child, and vice versa. The discussions of the General Committee of the Alpingi focused on this issue.

According to the majority of the General Committee, it would be difficult to maintain complete donor anonymity taking into consideration that also egg donation was suggested to be permitted: first, oocytes would have to be harvested in Iceland since the technology did not yet permit the freezing of oocytes and secondly, experience from other countries showed that recipients generally preferred to have a family member to donate eggs. In these conditions total anonymity would not be feasible. Consequently, the majority of the General Committee proposed a socalled double track policy, which allows the gamete donor to decide whether to be anonymous or identifiable and so enable recipients to choose either an anonymous or identifiable donor. If the recipients were to choose an identifiable donor the child would have access to the donor information at the age of 18. The gamete donor, in contrast, would not be able to receive information about the child unless the child initiated a contact. In addition, the majority of the General Committee proposed that gamete donors and prospective parents would be required to receive ade- 
quate information and be counseled on both the treatment itself and the medical, legal, and social consequences for all concerned. ${ }^{35}$

There were two dissenting opinions, one by Guðný Guðbjörnsdóttir from the Women's Alliance and another one by Hjálmar Jónsson from the Progressive Party. Guðbjörnsdóttir considered it problematic if the gamete donor was given the discretion of deciding whether the prospective child was to have access to donor information or not. Guðbjörnsdóttir suggested therefore that it should be up to the recipient of donor gametes to choose between anonymous and non-anonymous donor. Secondly, Guðbjörnsdóttir proposed that the bill's requirement of heterosexual relationship be removed. In this Guðbjörnsdóttir referred to the opinion of the Board of the University Hospital according to which the arguments for excluding single women and lesbian couples from infertility services were not sufficiently substantiated in the government proposal. ${ }^{36}$

The second dissenter, Hjálmar Jónsson, also discussed the issue of anonymity at length. Jónsson's misgivings about donor anonymity centered on two issues: first, the importance of genetic information for health care purposes and secondly, the increasing prevalence of human rights considerations in ART. ${ }^{37}$ Jónsson reminded that Iceland ratified the UN Convention on the Rights of the Child in 1992: "It is a basic human right to know one's origins. It constitutes one's understanding of oneself and there is a rich tradition of and will for that understanding among the Icelandic people. The 'legislator' does not have the power to deprive individuals of that right. Infertility should not be resolved at the cost of the human rights of those who are conceived with donor gametes.”38

As a result, the Alpingi adopted the double track approach that was suggested by the majority of the General Committee. ${ }^{39}$ The Act also in-

\footnotetext{
${ }^{35}$ Nefndarálit um frv. til 1. um tæknifrjóvgun (819). Frá meiri hluta allsherjarnefndar (SP, VS, SighB, ÖJ, KPál, ÁRA, JónK). 120. löggjafarping 1995-96. www.althingi.is/altext/120/2/0819.html 27.3.2005.

${ }^{36}$ Nefndarálit um frv. til 1. um tæknifrjóvgun (824). Frá 1. minni hluta allsherjarnefndar (G. Guðbjörnsdóttir). 120. löggjafarbing 1995-96. www.althingi.is/altext/120/s/0824.html 27.3.2005.

${ }^{37}$ Nefndarálit um frv. til 1. um tæknifrjóvgun (841). Frá 2. minni hluta allsherjarnefndar (H. Jónsson). 120. löggjafarbing 1995-96. www.althingi.is/altext/120/s/0841.html 27.3.2005.

${ }^{38}$ This is an excerpt of Jónsson’s dissenting opinion, translated by Ingileif Jónsdóttir.

${ }^{39}$ Article 4 reads that "Should a donor request anonymity, health workers must ensure that this wish be respected. In such cases information may not be provided to the donor on the couple receiving donor gametes, nor about the child, nor may the couple or the child receive information on the donor. - Should the donor not request anonymity, the institution shall keep information on the donor in a special file. Should the donation of gametes result in the birth of a child, data on
} 
cluded a requirement that more detailed rules on the implementation of the Act be issued by the Minister. These rules were prepared by the Ministry of Health and Social Security and the Regulation on Artificial Fertilization (568/1997) came into force in September 1997.

A provisional clause was added to the Act due to a parliamentary resolution that directed the Minister of Justice to appoint a new committee to monitor the implementation and effect of the Act. In October 1996 three members of the Committee - experts in law, medicine, and ethics - were appointed, led by Dögg Pálsdóttir. The Committee was appointed for a period of two years after which it was to report back to the Minister of Justice.

As required by its mandate, the monitoring Committee worked closely with the IVF unit at the Landspítali. The changes proposed by the Committee were to a large degree based on the experience gained at the unit. In its report the Committee suggested a number of minor changes to the Act adding a definition of cloning to the list of definitions in Article 1; changing the wording of Article 11 ("Research on Embryos") to lift the absolute ban on research ${ }^{40}$; and making the health record of the gamete donor available to the parents and to the child after she or he has turned 18, even in those instances where the donor has requested anonymity. 41

While the Committee was still working on its report, the Prime Minister decided that the implementation of the Act on Artificial Fertilization should fall under the responsibility of the Minister of Health and Social

the child and on the couple who received the donated gametes shall be kept in the same file. - A child conceived as a result of a donation of gametes, where the donor did not request anonymity, may at the age of 18 request access to the records as provided in para. 3 , in order to acquire information on the name of the donor. Should a child receive information on the gamete donor from the institution, the institution shall, as soon as possible, inform the donor that the information has been provided." - Notice, however, that all sperm used in Iceland for infertility treatment is imported from Denmark where donor anonymity is protected by law. The option provided by the Act on Artificial Fertilization is therefore merely theoretical (see, e.g., the Danish Council of Ethics 2002, 18).

${ }^{40}$ Currently, Article 11 sets out to ban all research on embryos: “All research, experiments and operations on embryos is prohibited.” The second paragraph of Article 11, however, allows four exceptions to what at first glance seemed to be an absolute ban: "Nevertheless, it is permitted to carry out research on embryos a) if it is part of an in vitro fertilization treatment, b) if the intention is to diagnose hereditary diseases in the embryos themselves, c) if the purpose is to advance the treatment of infertility, or d) if the purpose is to improve understanding of the causes of congenital diseases and miscarriages.”

${ }^{41}$ Skýrsla til dóms- og kirkjumálaráðherra frá eftirlitsnefnd með framkvæmd laga um tæknifrjóvgun 1998, 18-19. 
Security. ${ }^{42}$ Thus, when the Committee handed its report to the Minister of Justice in November 1998, the Minister of Justice simply forwarded it to the Minister of Health and Social Security who never acted on the report.

Recent developments in stem cell research are the factor that most imminently will require changes to the Act on Artificial Fertilization. In 2004 a group of MPs led by Jóhanna Sigurðardóttir made an initiative that called for a committee to look into allowing the use of embryonic stem cells for research and treatment, ${ }^{43}$ which is currently banned in the Act on Artificial Fertilization. In October 2005 the Minister of Health and Social Security appointed an expert committee to evaluate the use of stem cells for research and treatment and to draft a law on stem cell research. The committee is expected to finish its report by January $1^{\text {st }} 2006$.

There have also been calls for increasing the upper age limit of the couple receiving infertility treatment, ${ }^{44}$ as well as extending the maximum storage time of embryos ${ }^{45}$. Most recently, in connection with the opening of the private clinic, there have also been demands of making the law stricter with regard to the documentation of the procedures and outcomes, number of embryos implanted, and maximum age of gamete donors $^{46}$. The regulations on eligibility, on the other hand, have been suggested to be eased to include single women and lesbian couples. On August $8^{\text {th }} 2005$ Árni Magnússon, the Minister of Social Affairs, gave a speech (Magnússon 2005) at Hinsegin dagar, the annual festival of homosexuals. In his speech Magnússon expressed his support for the claims of homosexual people to gain the same rights to family life as those of heterosexual people. According to Magnússon, the main goal with adoption is to find a caring family for a child. The necessity of securing the best circumstances for a child to grow up and develop, being cared for and

\footnotetext{
42 The Act itself only refers to "the Minister."

${ }^{43}$ Tillaga til pingsályktunar um nýtingu stofnfrumna úr fósturvísum til rannsókna og lækninga. Flm. Jóhanna Sigurðardóttir et al. 131. löggjafarping 2004-2005. www.althingi.is/altext/131/s/0053.html 6.7.2005.

${ }^{44}$ According to the Regulation on Artificial Fertilization, “(a)s a rule, both partners shall be 25 years of age at the commencement of the treatment. As a rule, the woman shall not be older than 42 years at the commencement of the treatment. It is permitted to derogate from the specified age condition of the woman if a stored embryo, stored ovum or donor ovum is being used. The woman shall, however, never be older than 45 years when the embryo is transplanted and the husband or cohabitant, as a rule, shall not be older than 50 years" (Article 3 ).

45 According to the Regulation on Artificial Fertilization, embryos may be stored for a maximum of five years (Article 16).

${ }^{46}$ Current legislation does not set any age limit for gamete donors.
} 
loved can equally well be found in homosexual as in heterosexual couples. Magnússon also stated that "the same view applies to IVF treatment for lesbian women in health institutions. While we acknowledge that the desire to have a child is a precondition for heterosexual couples to get access to IVF treatment, in my mind it contradicts equal rights to deny lesbians access to such treatment” (Magnússon 2005). The speech was welcomed by interest groups and widely accepted by the general public as well as politicians from all parties.

An official at the Ministry of Health and Social Security reported that as soon as the first proposal for revision is brought forward, "we will also consider all the other suggestions for revision.” It seems likely that these revisions will occur in 2006.

The story of the IVF unit at the Landspítali was not an entirely happy one. Although the quality of the work of its medical team was rated high and the results of the unit were comparable to the best results achieved in similar clinics elsewhere, the unit faced frequent threats of being closed down as the Landspítali found itself under financial pressures. In these less than ideal working conditions Guðmundur Arason and porður Óskarsson decided to leave the Landspítali to start a private clinic. Initially, however, the Minister of Health and Social Security declined to grant a license ${ }^{47}$ on the grounds that operating two infertility clinics in a country the size of Iceland would not be cost-effective. Furthermore, an advocacy group called Tilvera ${ }^{48}$ was amongst those that lobbied against privatization for fear that it would raise the costs of infertility treatment. Finally, there were concerns expressed by a health policy expert about commercial pressures and absence of structure and supervision that a large university hospital is able to provide: "I understand that the pressure on the people working in the ART clinic is enormous from the couples. It is easy to understand: I want a child. Please give me a child. It's very hard to stand such pressure. Fortunately, we have been - or they have been doing very well, very well here. But anyone under pressure, I think -

\footnotetext{
${ }^{47}$ The Act on Artificial Fertilization requires that "Artificial fertilization may only be carried out at a health institution which has obtained a license from the Minister for that purpose and under the supervision of specialists in gynecology and obstetrics” (Art. 2.1).

${ }^{48}$ Tilvera, the Icelandic infertility association, was founded in February 1990 by couples who had received IVF treatment at the Bourn Hall Clinic. The association originally campaigned for the expansion of the IVF unit at the Landspitali. After being relatively inactive for a few years Tilvera was revived by the opening of the association's website in 2002 (www.tilvera.is 7.7.2005).
} 
maybe it is easier for them to work in an environment that has at least some fences, some limitations so they can say: Well it's not my decision, it is some people over there. (...) And (if) the physician becomes or is in the position of being the regulator, saying no I can't do this because this and that (...) then that of course puts a strain on the relationship between the doctor and the patient."

Regardless of these critical voices, the Minister of Health and Social Security finally granted the license in a letter dated on June $2^{\text {nd }} 2004$. In the letter, the Minister listed a number of conditions: 1) the costs of infertility treatment would not rise; 2) the quality of the services would be ensured; 3) waiting times would not lengthen; and 4) an adequate level of surveillance would be ensured. In addition, under the consultation of the Ministry of Health and Social Security, a service contract would be negotiated between the Landspítali and the private clinic. The terms of the service contract, finalized in November 2004, stipulated among other things that the private clinic and the Landspítali would collaborate on teaching and research in the area to each party's mutual advantage. A few days later ART Medica opened its doors and the IVF unit at the Landspítali ceased to exist.

In a nation the size of Iceland it is likely that practically any group of actors wishing to influence the outcome of a policy designing process will be able to do so. This notwithstanding, the designing process in Iceland is most accurately described as designing by experts, defined by "congruence of interests and beliefs among the important actors, a favored and uninterrupted designing process, and a substantial design output according to the dominant beliefs of the most resourceful actors" (Rothmayr et al. 2004, 251). In the case of Iceland, the general agreement on several important policy goals and the strong presence of the medical practitioners in the designing process assigns the country to this designing category resulting to an intermediate ART policy design. 


\section{Denmark}

Denmark is the most recent Nordic country to pass comprehensive legislation regarding assisted reproduction. The Danish ART policy designing process cannot be characterized as a particularly speedy one. From the time the first governmental committee on ART released its report in 1984, it took thirteen years to enact a law. During this interval the practice of assisted reproduction was very liberal despite a number of regulations that were in place. Thus, single women and lesbian couples were offered treatment at private infertility clinics and surrogate motherhood was being practiced, albeit to a limited extent. The Act on Artificial Fertilization (460/1997) was adopted in May 1997 after intense deliberations and, at times, chaotic proceedings in the Danish Parliament, the Folketinget. One of the most controversial issues was the access of single women and lesbian couples to assisted reproduction. Although the country is famous for its sexual liberalism - Denmark was, after all, the first country in the world to legalize same-sex unions - the Act on Artificial Fertilization restricts access to ART to heterosexual couples. This issue continues to cause friction in the Folketinget - even more so after a midwife opened a clinic in Copenhagen offering donor insemination to single women and lesbian couples. Numerous proposals and counter-proposals regarding the issue of access have been introduced in the Folketinget over the years. In its deliberations the Folketinget has the Council of Ethics on hand to give advice and information on ethical questions. The Danish Council of Ethics epitomizes the country's long tradition of citizen participation and public consultation. The Council of Ethics played a significant part in the process in which the initial rather narrow view of ART as a merely medical matter was replaced by a more comprehensive view of ART as an ethical, social, and medical issue. At the same time, the Danish health care system has been able to make fertility services available to the highest proportion of the population in Europe. In consequence, 3.7\% of all the children born yearly in Denmark are conceived with the help of assisted reproductive technologies.

In the business of ART, Denmark is known worldwide as the home of Cryos International Sperm Bank Ltd. Established in 1987 in Aarhus, 
Cryos started a donor program in 1990. The program expanded quickly, first exporting donor sperm to several countries in Europe and gradually outside the continent to destinations including Paraguay, the United States, Kenya, and Hong Kong. Company website boasts that Cryos now caters close to 50 countries around the world. A January 2000 edition of The Wall Street Journal ran a headline announcing that “A Most Unlikely Industry Finds It Can’t Resist Globalization’s Call - Exporting Human Sperm Is A Fast-Growth Business, Banks in Denmark, U.S. Find” (Zachary 2000). The article explains the growing demand for exported sperm: "For sperm banks, technology plays a major role in the globalization drive. Concern about genetic defects and infectious diseases has led to sophisticated and expensive means of testing donations. Storage and transport methods have grown more complicated, too. The improvements add to the investment required to operate a sperm bank. That, in turn, promotes consolidation: Only those banks that can do large volumes of business think it's worth offering sperm for sale” (Zachary 2000). Cryos has been able to carve out its niche in the global market because Danish sperm has a reputation for being of high quality and, in contrast with the law in the other Nordic countries, the Danish Act on Artificial Fertilization continues to protect donor anonymity. In addition, as The New York Times reports in September 2004, Danish culture, "famously secular and sexually liberal, holds an uncomplicated view of sperm donation” (Alvarez 2004). Moreover, the managing director of Cryos, Ole Schou, does not attempt to conceal his global ambitions: "We think we can be the McDonald's of sperm" (Zachary 2000).

The evolution of ART in Denmark began with research into IVF in the 1970s. After the initial research phase the development of IVF was punctuated by the birth of the first Danish test-tube baby in 1983, the authorization of the method by the Ministry of Health in 1986, and the approval of IVF as a public hospital service in 1987 (The Danish Council of Ethics 1995, 14). ${ }^{49}$ At present, the Danish health care system makes fertility services available to the highest proportion of the population in Europe: "Denmark is way ahead of everyone else with 1,826 cycles per million of the population performed in 2000. Out of all the children born in Den-

\footnotetext{
${ }^{49}$ A prominent Danish feminist Lene Koch criticizes the decision by the National Board of Health to approve IVF as a public hospital service in Denmark, since it failed to subject the method to medical technology assessment which already was established as a standard procedure (Koch 1991, 49-50).
} 
mark that year, 3.7\% were ART babies," reports Karl Nygren, one of the three authors of the fourth ESHRE report on ART in Europe (Andersen, Gianaroli \& Nygren 2004; see Women's Health Weekly 2003, 12). Another author, Anders Nyboe Andersen estimates that "Denmark has nearly reached saturation point, with hardly anyone who wants fertility treatment having to wait” (Women's Health Weekly 2003, 12).

Despite the rapid developments in the 1980s, the regulation of ART remained fragmented and sparse until the Act on Artificial Fertilization entered into force in 1997. However, this does not imply that the provision of assisted reproduction in the country went on without any oversight. Throughout the 1980s and 1990s reports were written, policies were contemplated, and a number of guidelines, circulars, and executive orders were issued to address the increasing use of technology in human procreation.

In 1983, the year of the birth of the first Danish test-tube baby, the Danish Ministry of the Interior established two committees to investigate "the need for regulation of safety issues on the one side and ethical issues on the other" (Jamison \& Lassen 2004, 39). This first initiative by the Danish government resulted in what Jamison and Lassen call a 'split accountability' of biotechnology assessment whereby the human and the non-human applications of biotechnology were to be evaluated by two separate sets of criteria, one focusing on ethical and social issues and the other focusing on safety issues (Jamison \& Lassen 2004, 39-41). The Committee for Gene Technology was to draw up a plan for the organization of the public administration of biotechnology with a specific focus on the risks to the environment and to humans. The Committee on Ethical Problems Regarding In Vitro Fertilization, Artificial Insemination, and Fetal Diagnostics, set up in April 1984, was to look into the ethical problems associated with gene technology, in vitro fertilization, artificial insemination, and fetal diagnostics.

The Committee on Ethical Problems Regarding In Vitro Fertilization, Artificial Insemination, and Fetal Diagnostics published its report "The Price of Progress” (Indenrigsministeriet 1984) in 1984 concluding that no specific legislation was needed. Instead, the Committee recommended that an independent ethical council for health care services be established and the issue of ART regulation left for the council to decide upon (Conradsen 2002, 69). 
In June 1987 the Folketinget adopted the Act on the Establishment of an Ethical Council and the Regulation of Certain Forms of Biomedical Experiments, and the Danish Council of Ethics began its work in 1988. The Council has two main functions: 1) to advise the Folketinget and the Ministry of Health on the ethical problems arising with the development of new techniques and treatments in health care; and 2) to inform the general public and to promote public debate on ethical problems in the field of health (The Danish Council of Ethics 2003, 5). Section 1 of the 1987 Act provides that the Council will "carry out its work on the assumption that human life begins at the moment of fertilization." This provision was added at the request by the Christian People's Party during the parliamentary debate on the bill. It was anticipated, according to Inger Marie Conradsen, that the provision would "re-open the abortion debate" from the 1970s but, as Conradsen concludes, "it has had little, if any, practical implications” (Conradsen 2002, 70). When the government bill on the Danish Council of Ethics was introduced to the Folketinget in March 2004, the provision was omitted but, again at the request of the Christian People's Party, a similar provision was added. Section 1 of the Act on the Danish Council of Ethics (440/2004) reads now that "respect for the integrity and dignity of the human being also encompasses the early phases of human life, including fertilized human eggs and embryos."

The 2004 Act on the Danish Council of Ethics expanded the Council's mandate so that the Council now gives advice and information on ethical issues pertaining to "human beings, nature, the environment and foodstuffs" to the Folketinget, the public authorities, and the general public. Although the Act does not require an equal representation of lay people and experts, the Council follows the country's tradition of lay technology assessment by including a significant number of lay people (Nielsen \& Faber 2002, 38).

In 1992 the Folketinget passed the Act on a Scientific Ethical Committee System and the Handling of Biomedical Research Projects, parts of which regarded experiments on ART. Among other things, the Act authorized the Ministry of Health to issue regulations on the cryo preservation and donation of eggs. It also prohibited the donation of human em- 
bryos (The Danish Council of Ethics 1995, 26; Conradsen 2002, 8586). ${ }^{50}$

In August 1993 two cases in Danish private infertility clinics stirred a national debate on assisted reproduction (Dolley 1993). The first case was about a woman who became pregnant with nine embryos after having received hormone treatment at a private infertility clinic. The woman did not find out that she was carrying nine fetuses until the twelfth week of gestation. ${ }^{51}$ In the second case a doctor fertilized a donated egg with donated sperm and transferred the resulting embryo to a woman. The doctor was later charged with breaking the Act on a Scientific Ethical Committee System, which banned embryo donation. ${ }^{52}$ The two cases drew public attention to the quality of care in the private sector as well as to the risks and dangers of hormone treatment.

These concerns were addressed only two months later, in October 1993, at the Consensus Conference on Infertility organized by the Technology Board together with the Research Committee of the Folketinget and the Council of Ethics. In the final document of the Conference the lay panel recommended that techniques for hormone treatment should be developed in order to avoid multiple pregnancies. The panel also recommended that "a central registration system should be introduced in order to keep track of treated patients and their possible offspring. In this way, consequences of the treatment, e.g. long-term effects of hormone treatment, could be disclosed" (The Danish Board of Technology 1993).

Soon after that, following a number of legislative initiatives in the Folketinget, the Danish IVF Register was established in January 1994. The register covers all treatments with IVF, ICSI, FER, and egg donations. Each clinic is obliged to report each treatment cycle and the pregnancy outcome to the register. ${ }^{53}$

${ }^{50}$ A Ministry of Health regulation (22.7.1992/650) issued under the 1992 Act specified that egg donation had to be anonymous and stipulated that frozen eggs, fertilized or unfertilized, could be stored for a maximum of one year.

${ }^{51}$ To decrease the risk for maternal and fetal complications fetal reduction is usually recommended when there are three or more fetuses. The procedure is most successful when performed between 10 and 12 weeks of gestation. At present, fetal reduction is regulated in the Act on Abortion and Fetal Reduction of 2004.

52 The case was tried by the Court of Ballerup. In its Lundstrøm ruling in March 1994, the Court acquitted the doctor because "there was no reason to undertake an expansive interpretation of the provision, whereby the ban would also cover the donation of unfertilized eggs subsequently fused with donated sperm” (The Danish Council of Ethics 1995, 33).

${ }^{53}$ For a discussion on the Danish IVF Register, see Andersen, Westergaard \& Olsen 1999. 
In January 1994 the Folketinget adopted a resolution on the approval of new methods of assisted reproduction. From then on, all new methods of treatment that doctors wished to start using were to be subjected to a health-professional evaluation by the National Board of Health and to an ethical evaluation by the Council of Ethics. After having received these two evaluations, the Ministry of Health decides whether the treatment is to be approved (Conradsen 2002, 90-91).

Although a number of investigations in Denmark had taken the ethical and social aspects of assisted reproduction into consideration, the existing regulations addressed primarily the medical aspects of assisted reproduction as some of the titles of the circulars and guidelines imply: "Guidelines on Physicians' Use of Assisted Reproduction and Other Forms of Reproduction-enhancing Treatment"; "Circular on the Reporting of IVF Treatment"; and "Circular on Registration by Physicians of New Forms of Treatment Aiming to Establish Pregnancy."

One of the reasons for framing assisted reproduction as a predominantly medical issue was that the regulation of ART in Denmark falls within the scope of the Ministry of Health. Also, the fact that the practice of assisted reproduction in Denmark was quite liberal prior to the 1997 Act suggests that the focus may not have been, initially at least, "on the social risks of ART or on its implications for family life" as an official at the Ministry of the Interior and Health pointed out. Thus, private clinics treated all women irrespective of their age or marital status. Surrogacy was not prohibited by law as long as it did not involve monetary compensation or the use of a middleman. And, as a 1995 report by the Council of Ethics testifies, such arrangements did indeed take place: "There are known to have been only very few instances in Denmark where permission has been given for adoption under such circumstances” (The Danish Council of Ethics 1995, 37).

The common perception of ART as first and foremost a medical matter seems to have been shaken by the 1995 report entitled "Assisted Reproduction" by the Danish Council of Ethics. According to an official at the Ministry of the Interior and Health, "the ethical questions came more into focus" along with the Council of Ethics report. In that report the Council states that its "primary task must be to take an ethical stance on assisted reproduction” (The Danish Council of Ethics 1995, 13) because, as it pointed out later on, "the application and spread of assisted reproduc- 
tion may be perceived as a threat to (...) significant collective benefits or values" (The Danish Council of Ethics 1995, 56). This premise led the Council to a general conclusion that governmental oversight of assisted reproduction needed to be increased.

However, when it came to the specifics of governmental oversight, a variety of opinions emerged. This is, of course, the case with all the deliberations of the Council and in accordance with its philosophy: differences of opinion are not to be glossed over by a forced consensus. As one of the Council's former chairpersons put it, "the Council of Ethics is not an oracular institution whose mission is to tell the politicians and everyone else what to think and do" (The Danish Council of Ethics 2003, 6). In the Council's 1995 report, alternating constellations of minorities and majorities yielded vastly different and at times diametrically opposed recommendations. Thus, because of "an extensive degree of respect for the individual's right of self-determination” (The Danish Council of Ethics 1995, 11) in Denmark, a minority of the Council felt that the existing level of regulation was adequate. In fact, the minority recommended that some of the restrictions that were in place at the time ought to be relaxed. These included extending the maximum storage time of frozen embryos, permitting embryo donation, and giving up the requirement that only women who were undergoing infertility treatment themselves were allowed to donate eggs. The majority of the Council, on the other hand, was of the opinion that assisted reproductive technologies "involve changes to our view of human life and of reproduction itself, changes which appear to affect social and cultural development in an unwished-for direction" (The Danish Council of Ethics 1995, 10). For that reason, various coalitions within the majority recommended that a number of the then available methods should be "phased out" altogether. These included, depending on the coalition, IVF, the freezing of embryos, and gamete donation.

Government bill L200 on artificial fertilization was introduced to the Folketinget in February 1996. The bill was the product of Poul Nyrup Rasmussen's second government of Social Democrats, Radical Liberals, and Center Democrats and its approach was rather permissive. Among other things, the bill allowed the treatment of single women and lesbian couples; it set the woman's upper age-limit for participating at menopause; and it allowed both sperm and egg donation. As a February 1996 issue of Lancet reported, the bill "provoked heated debate" in Denmark 
(Skovmand 1996). Since the bill dealt with an ethically controversial issue, MPs were allowed to vote in accordance with their conscience. Deviation from party line voting is a fairly exceptional event in Danish parliamentary politics, which typically exhibits a high level of party discipline (Damgaard 2004, 123). The Danish parliamentarians were more than happy to seize the moment for they presented a total of 55 questions to the Minister of Health and produced a total of 79 amendments that covered a vast array of issues from the title of the bill to the revoking of donor anonymity (Albæk 2003, 257; Conradsen 2002, 92). Because of the chaos that ensued from this unprecedented parliamentary activism, the bill did not proceed to its second reading (Lüttichau 2004, 83). A new bill, L 5, was introduced in October 1996. The MPs now introduced a total of 24 amendments and presented 66 questions to the Minister of Health (Conradssen 2002, 92; Lüttichau 2004, 83). This time, however, the bill proceeded to its third reading and was adopted in May 1997.

The controversy arose mainly from three issues: 1) the upper age-limit for the woman receiving infertility treatment; 2) the issue of financing assisted reproduction; and 3) the treatment of single women and lesbian couples. The medical community appears to have been quite vocal with regard to the issue of the age-limit. According to the doctors, infertility treatment for women over 40 has limited chances of success. ${ }^{54}$ The doctors pointed out, furthermore, that the already existing problem of waiting lists would worsen if older women were to become eligible for treatment at public hospitals (Skovmand 1996). The Folketinget decided that the age-limit for women undergoing infertility treatment should be 45 years in both the public and the private sector. It also agreed that assisted reproduction would be offered at the public hospitals free of charge, although "several politicians from different political corners expressed a wish that this should be a subject for further discussion" (Skovmand 1997).

In the first reading of L200, three MPs from the Social Democratic Party - one of the government parties - proposed an amendment accord-

\footnotetext{
${ }^{54}$ Most of the medical organizations and institutions that sent a comment on the bill to the Ministry of Health suggested that the bill be amended to have an age-limit: Den Almindelige Danske Lægeforening 10.11.1995, Rigshospitalet 6.11.1995 (45 for women, 55 for men), Fertilitetsklinikken i Ballerup 10.11.1995 (50 for women, 55 for men), Gynækologisk afdeling, Århus Kommunehospital 7.11.1995 (45, not specified whether for both men and women or for women only), Genetisk Netværk 8.11.1995.
} 
ing to which infertility services should only be offered to women who are married or living with a man in a stable, marriage-like relationship. They argued that the wellbeing of the child lay in having both a mother and a father. The amendment was adopted after the first reading of the bill and became section 3 of the Act on Artificial Fertilization: "Medically assisted procreation shall be made available only to women who are married or live with a man in a de facto marital relationship."

Prior to the 1997 Act assisted reproduction was available to single women and lesbian couples at private infertility clinics. The closure of this possibility is, arguably, the single most controversial aspect of the 1997 Act since it appears to stand in contrast with the country's overall culture of inclusiveness and sexual liberalism. ${ }^{55}$ The proponents of section 3 had to refute accusations of discriminatory intent on their part: "I'll say it now and I hope it is the last time I have to say it to Ms. Yvonne Herløv Andersen: It is not discrimination. We want to ensure that the child - somehow - has a father and not just a handful of sperm and here we have to think of the child. The child is the weak party in this regardless of what Ms. Yvonne Herløv Andersen tries to tell me and others in this matter" (an MP from the Socialist People’s Party, cited in Albæk 2003, 259).

A representative from the Progress Party protested against section 3 saying that "if a woman is artificially inseminated, then I feel it is her decision. The state should not interfere. The state should not be the moral guardian on this issue” (Cited in Albæk 2003, 260). The opponents of section 3 introduced two bills in the fall of 1997 and in the spring of 1998 to repeal the section. The first bill was withdrawn when an election was called in February 1998. It was reintroduced in the new Folketinget in April 1998, but was rejected in June 1998. In October 1999 midwife Nina Stork opened a private infertility clinic in Copenhagen. The clinic, StorkKlinik, offers donor insemination regardless of "the ethnic background, religion, civil status or sexual orientation” 56 of its clients. The clinic operates within the confines of the Danish law since the 1997 Act applies to infertility treatments performed by or under the supervision of a physician. MPs from the Christian People's Party and the Conservative Party

\footnotetext{
55 The issue has been discussed in a number of scholarly papers. See, for example, Lüttichau 2004, Albæk 2003, and Bryld 2001.

${ }^{56}$ www.storkklinik.dk 10.5.2005.
} 
have argued on several occasions that the existence of the clinic is against the spirit of the law, vowing to close the loophole (Lüttichau 2004, 8384).

When the Minister of Health introduced a statutory revision bill to the Folketinget in February 2000 the issue of access flared up again. Altogether 33 amendments were introduced, among them an amendment by MPs from the Christian People's Party and the Conservative Party proposing the introduction of a user's fee. The amendment also included a provision that donor insemination only be performed under a physician's supervision. The amendment was rejected because, as Lüttichau explains, "the left-wing parties of Parliament made a collective vote against the Bill, arguing that it broke with the principle of free hospital treatment" (Lüttichau 2004, 84). In the end the government was forced to withdraw its proposal.

Following a parliamentary debate on xenotransplantation in the Folketinget in January 2001, the Minister of Science, the Minister of the Interior and Health, and the Minister of Justice were instructed to set up a committee on gene technology. The task of the committee was to write a report, which would shed light on the possibilities and risks of modern biotechnology. The committee released its report "Biotechnologies of the Future - Possibilities and Risks" in October 2002. In connection with a parliamentary debate on the report, the Folketinget adopted a resolution in November 2002 requiring the government to introduce a bill on embryonic stem cells in early 2003. The Minister of the Interior and Health consequently introduced a bill, L209, on embryonic stem cell research to the Folketinget in April 2003. The bill was approved in June 2003 and the Act on Artificial Fertilization was amended with a new section stipulating that research on human embryos is allowed "if the purpose of experiments involving the use of fertilized oocytes and stem cells derived therefrom is to obtain new knowledge that could improve the possibilities of treating diseases in human beings.” Only leftover embryos, i.e. embryos which are no longer needed for infertility treatments, may be used for research.

As the Minister of the Interior and Health introduced L209 to the Folketinget he said that the government was of the opinion that the Act on Artificial Fertilization needed re-evaluation and the government was going to initiate a parliamentary debate on the subject in the next parliamen- 
tary session. The governmental coalition at the time, the first government of Anders Fogh Rasmussen, was composed of the Liberal Party and the Conservative Party. In March 2004 the Minister of the Interior and Health introduced a bill, L187, to amend the Act on Artificial Fertilization. The bill proposed five changes to the 1997 Act: 1) public hospitals may treat couples up to the birth of one child only; 2) the Ministry of the Interior and Health may issue pertaining criteria for assessment of parental suitability; 3) the National Board of Health may allow the use of PGD-HLA in cases where an existing child has a life-threatening disease; 4) human eggs and embryos may be stored in public hospitals until a couple has a child, after which the eggs and embryos will be destroyed, donated for research or transferred to a private clinic for subsequent treatments; and 5) human eggs and embryos may be stored for up to five years.

The portion of the bill regarding preimplantation tissue typing (L188) was taken to a separate, expedited handling because of a case in Denmark involving a child afflicted with a non-hereditary disorder. That particular portion was accepted and the amendment entered into force within a month, in April 2004. The rest of the bill was discussed once in the Folketinget. After the first reading of the bill it was decided that the Folketinget would return to the matter in its next session. The bill, however, was not reintroduced to the Folketinget when it reconvened in October 2004. Instead, in December 2004 the Ministry of the Interior and Health turned to the Council of Ethics for advice on the same issues that had been taken up in L187. In addition the Ministry asked the Council to comment on the following scenario: Single women and lesbian couples would have access to assisted reproduction in the country's private clinics at their own expense. In order to provide the prospective child with a father, the scenario includes the abolishment of donor anonymity. The Council of Ethics submitted its consultative reply in April 2005 (Det Etiske Råd 2005). The Council was in accord that the prospective child's needs should be given the highest priority with regard to issues such as donor anonymity and parental suitability, but could not agree on what, specifically, would be the outcome of that position. Not one of the members, however, approved of the scenario where donor anonymity would be abolished only in the case of single women and lesbian couples. Instead, the majority of the Council was in favor of removing donor anonymity altogether. In addition, the majority was in favor of providing 
fertility services at public hospitals to all patient groups, including single women and lesbian couples.

The Danish ART policy designing process falls into a category that Rothmayr et al. identify as designing by mobilization and consultation (Rothmayr et al. 2004, 250-251). In Denmark, the policy designing process has included lay technology assessment, public participation, and dialogue between policymakers, experts, and ordinary citizens. The fact that this has led to an intermediate ART policy design in a country that by all accounts is the most liberal of the five Nordic nations requires some explanation. A study surveying the attitudes among Danish health care professionals on the ethics of assisted reproductive technologies and legal abortion (Fonnest et al. 2000) found that the views of the Danish medical community were relatively restrictive with regard to issues such as sex selection, adoption by gays and lesbians, and access to ART by single women and lesbian couples. This indicates that the Danish medical community may not have pushed for a more permissive ART policy design. Moreover, the shifting of the emphasis from ART as a predominantly medical to a predominantly ethical issue may have contributed to the placement of Denmark in the intermediate category. This appears to entail a paradox since the Council of Ethics, the principal architect of ART as an ethical issue, has itself taken a fairly liberal stand on ART in its recent deliberations.

An unusual characteristic of the Danish situation is the fact that the law grants access only to heterosexual couples but, because of a loophole in the law, single women and lesbian couples can access infertility services via a single clinic in Copenhagen. In consequence, although the intended policy design is intermediate, the practice of ART in Denmark falls in the parameters of a permissive design. 


\section{Finland}

It has become somewhat of a national sore point that Finland is the only Nordic state yet to implement legislation concerning assisted reproduction. The lack of legislation does not imply a lack of effort, however. There have been several proposals to introduce legislation since the 1980s. The two decades of legislative effort mark one of the most difficult challenges ever faced by Finnish lawmakers. The sole proposal so far to reach the Finnish Parliament, Eduskunta, resulted in a revolt of sorts that forced the government to withdraw its proposal. In the meantime Finnish infertility doctors have been able to experiment with a wide range of treatments offering the most permissive regime of assisted reproduction in the Nordic region. Single women and lesbian couples have access to assisted reproduction, surrogacy is practiced, and all forms of donor conception are available. Although the absence of legislation is a source of concern for many, it has enabled Finnish infertility doctors to excel in clinical practice. Among other things, they have been the first doctors in the Nordic countries to combine single embryo transfer with an embryo cryo preservation program resulting in the reduction of multiple pregnancy rates to the lowest of the Nordic countries (Hazekamp \& Hamberger 2005).

Up until fairly recently, the Finnish medical community has been opposed to government regulation of assisted reproduction (Malin \& Burrell 2004, 86). The physicians have argued that strict control would deter medical progress in the field, prevent the introduction of new treatment methods, and put an end to some of the treatments that have proven to be effective and beneficial. Furthermore, according to the physicians, legislation is unnecessary to begin with since no cases of misuse have emerged.

Because, indeed, no major scandals have been unearthed, regulation of assisted reproduction has not been high up on the list of political priorities. In the 1990s especially, other issues queued up at the top of the list. The breakup of the Soviet Union in 1991 and the following worldwide economic turbulence had severe repercussions for Finnish politics and 
economics. A quarter of Finland's export market in formerly communist Eastern Europe imploded and Finland's economy plunged into a recession. Social security cuts gave rise to speculations of a forthcoming breakdown of the welfare state. The unpredictability of the developments in Russia increased the fear of external threats such as uncoordinated immigration, nuclear plant accidents close to the Finnish border, and the importation of illegal drugs, prostitution, and organized crime. In 1995, Finland became a full member of the European Union and was the only Nordic country to join the Economic and Monetary Union in 1999. In the midst of an economic recession, European integration, and a crumbling superpower next door, assisted reproduction was not an issue capable of stirring political passions and ambitions.

This notwithstanding, the law drafting process had been taken up and was quietly progressing behind closed doors in the Ministry of Justice and the Ministry of Social Affairs and Health. Fairly early in the process, two kinds of disagreement emerged: one regarding the anonymity of the donor - or the prospective child's right to learn the identity of the donor and another one regarding the provision of services to single women and lesbian couples. A third point of disagreement emerged in 1996 when a third Ministry of Justice working party proposed that surrogacy be permitted. These three issues have been the primary hindrance to the adoption of a law on assisted reproduction.

The fundamental principle underlying the entire legislative effort has remained constant from the very beginning: the protection of the rights and interests of children born as a result of the use of assisted reproduction. The emphasis on the child came about as a result of a series of law reforms that took place in the 1970s. Most important of these was the birth of child law. In the course of the 1970s, developments in family law led to the birth of this new branch of family law. Child law took place with the enactment of several laws, known collectively as 'the child package.' All the laws that comprised the child package shared one common feature: an emphasis on the child as an individual. This meant that the rights and interests of the child were to be protected independently from those of the parents. The primary goal of the child package was to ensure that all children have the same legal rights irrespective of the marital status of the parents (Kurki-Suonio 1999). However, while the emphasis on the rights and interests of the child is widely accepted as the guid- 
ing principle, the question of how to best apply it in the domain of assisted reproduction has been open to a variety of interpretations over the years.

The task of the first ART working party, set up by the (former) National Board of Health in 1982, was restricted to the ethical and legal issues related to artificial insemination (Lääkintöhallituksen työryhmä 1984, 1). Although the first working party had a narrower focus than the subsequent working parties, its work was of formative nature. Its emphasis on the rights of the child was adopted by all the subsequent working parties. In addition, the dividing line that formed between the lawyers and the physicians on the working party came to signal one of the most polarizing issues in the two decades of law drafting: the issue of donor anonymity. Physicians opposed the idea of giving the child a right to learn the identity of the gamete donor, mainly out of fear of diminishing the donor pool (Malin \& Burrell 2004, 86). They also viewed the donor as a benefactor, someone who was there to help others out of benevolence, and therefore someone who should not be subjected to any additional inconvenience. Lawyers, on the other hand, were mostly in favor of giving the child a right to learn the identity of the donor. Their opinion was based on a legal principle that required that each individual have access to any and all documents containing information on that individual.

The first comprehensive proposal on assisted reproduction in Finland was drafted by a working party appointed by the Ministry of Justice in 1987. The working party reported in 1988 (Oikeusministeriön työryhmä 1988), recommending that 'artificial reproductive technologies' should be subject to the licensing authority of the National Board of Health. The proposal restricted access to married or cohabiting couples who were involuntarily childless or whose offspring were likely to inherit a serious disease. Permitted techniques included insemination, IVF, embryo transfer, and the use of donated gametes and embryos. The donation of gametes would establish no legal relationship between the donor and the prospective child. The donor would not be given any information on the recipients or the child. The child, however, upon attaining 18 years of age, would have a legal right to learn the identity of the donor.

In contrast with the newly enacted Swedish ART legislation, the proposal of the all-female, all-lawyer Finnish working party permitted egg donation. Whereas the Swedish law was based on the notion that the bio- 
logical difference in male and female reproductive physiology carried important ethical implications, the Finnish ART working party regarded the issue as one of equality in health care. A member of the working party recounted that "from the very first meeting on, it was self-evident that there had to be equal opportunities to treat both male and female infertility. The issue was not even debated.” And since both sperm and egg donation were to be allowed, it seemed logical to allow embryo donation as well.

The composition of the first working party was a red flag to many. A proposal written by a group of women lawyers was not seen as an authoritative one. In addition, expert opinions on the proposal were strongly divided on recipient eligibility and donor anonymity, and the working party concluded that the proposal needed further work.

A second proposal (Oikeusministeriön työryhmä 1990) was published in 1990 by a second Ministry of Justice working party, this time including two male physicians. The major difference between the 1988 and 1990 proposals was that the latter recommended that the child have no legal right to discover the donor's identity. In other relevant aspects, the 1990 proposal was the same as the previous one. Because a disagreement in the working party on donor anonymity prevented the proposal being presented to the Eduskunta, the process of drafting the legislation continued at the Ministry of Justice. This resulted in an unpublished report dated on June $24^{\text {th }} 1993$, parts of which were made public later on. The report proposed a compromise on donor anonymity in which the National Authority for Medicolegal Affairs ${ }^{57}$ would be given the discretion of deciding whether or not the identity of the donor was to be disclosed to the child upon reaching the age of 18, but only in cases where the child's health or well-being required such disclosure (HE 76/2002, 24-25).

Since none of the proposals thus far had led to a government bill, the National Research and Development Center for Welfare and Health (STAKES) produced a proposal of its own. "The STAKES Working Group Proposal to Hasten the Drafting of an Act on Infertility Treatments” (STAKES 1996) suggested the kind of 'double track' policy to the issue of donor anonymity that was adopted in the Icelandic ART legisla-

\footnotetext{
57 The National Authority for Medicolegal Affairs is an agency under the Ministry of Social Affairs and Health. It is responsible for maintaining and promoting patient safety and for safeguarding the quality of health care services (www.teo.fi 22.9.2005).
} 
tion. The so-called double track policy is a compromise that allows the donor to decide whether to be anonymous or identifiable and so enable recipients to choose either an anonymous or identifiable donor. The STAKES working group also revised the terms employed in the earlier proposals, arguing that 'artificial reproduction' was outdated and misleading and should be substituted with 'infertility treatment'. This was in accord with the wishes of the Finnish infertility doctors who had been facing accusations from fellow physicians of providing "elitist" and "unnatural" treatments. Although the treatments had been steadily improving - delivering more babies and less side effects - there were persistent questions about priorities in health care delivery as well as religious acceptability of the treatments. In an effort to present their work in a more positive light, infertility doctors wanted the terminology to create a more positive image of assisted reproduction to others.

The third Ministry of Justice working party complied with the wishes of infertility doctors by dropping the term 'artificial reproduction' in favor of 'fertility treatment' which became the prevalent parlance from then on. The working party's proposal, “The Use of Gametes and Embryos in Medical Fertility Treatment”, published in October 1997 (Oikeusministeriön työryhmä 1997) suggested two significant changes to the previous proposals. First, a rather complicated provision on the access of the prospective child to donor information was drawn up. It read in essence that the child, upon attaining 18 years of age, would have a right to learn the donor's identity provided that the donor had consented at the time of the donation or had consented after being informed by the National Authority for Medicolegal Affairs that such a request had been made by the child. ${ }^{58}$ Secondly, the working party suggested that surrogacy arrangements be permitted under certain conditions. ${ }^{59}$

\footnotetext{
${ }^{58}$ Even in the absence of donor consent, the child would be entitled to know the donor's identity when the donor had been dead for ten years. Upon attaining 18 years of age, the child would also be entitled to receive a self-description written by the donor and which the donor would be required to provide at the time of donation.

59 The 'use of a surrogate', as worded by the working party, required that (1) the National Authority for Medicolegal Affairs had given its authorization to the arrangement, (2) both the surrogate and the intended parents were each at least 25 years of age, (3) the husband of the surrogate had consented to the arrangement, in case the surrogate was married, (4) the surrogate had given her informed consent to the procedure, (5) her motivation was an altruistic one, and (6) she was reimbursed only for the direct expenses associated with her participation.
} 
Unlike the previous proposals, the 1997 proposal resulted in a vivid public discussion centered on the issue of access of single and lesbian women to assisted reproduction. Public interest in the issue was unexpected since the eligibility criteria had remained the same since the very first paper proposing legislation. The newly awakened public interest was due, in part, to the fact that in the course of the 1980s and 1990s other Nordic countries had passed legislation allowing couples in same-sex relationships to register their partnership in a manner and effects similar to those of marriage. Finland was now following suit. The Act on Registered Partnerships of 2001 was under preparation in Finland at the time, drawing public attention to the legal status and rights of gay and lesbian couples.

As in the past, the requested expert opinions were strongly divided on the issues of recipient eligibility, donor anonymity, and now surrogacy. About one half of the experts opposed surrogacy. It was pointed out that, among other things, surrogacy was banned in most European countries, not to mention in all other Nordic countries. Were Finland to permit surrogacy, it would not only mark a deviation from the principle of legal uniformity among the Nordic countries but also expose the country to a legitimate market in reproductive tourism ${ }^{60}$ (Oikeusministeriön työryhmä 1998).

Several of the controversial provisions were then modified in a 1998 unpublished proposal by a joint Ministry of Justice and Ministry of Social Affairs and Health working party (Oikeusministeriön työryhmä 1998). Because of the practical as well as ethical problems surrounding surrogacy arrangements, the working party concluded that surrogacy should not be permitted. At that time, Helsingin Sanomat published an opinion

\footnotetext{
${ }^{60}$ Surrogacy arrangements have been carried out in Finnish infertility clinics since the early 1990s. Viveca Söderström-Anttila and nine other Finnish infertility specialists reported in 2002 (Söderström-Anttila et al. 2002) that between January 1991 and May 2001 altogether 17 couples had attempted one or more IVF surrogacy cycles in four different clinics in Finland. The surrogate mothers were unpaid volunteers: six sisters, three mothers, one husband's sister, one cousin, four friends and three other volunteers. Four of the commissioning couples came from other Nordic countries: two from Sweden, one from Norway and one from Denmark. In all cases, the commissioning parents were the genetic parents of the child born to the surrogate mother. Since unwritten law regards the woman who gives birth to the child to be the legal mother of that child, the commissioning parents were required to adopt the child after birth. Although SöderströmAnttila et al. reported two cases of postpartum depression, they concluded that “...in our experience IVF surrogacy has shown a high success rate and a gratifying outcome for all parties involved" (Söderström-Anttila et al. 2002, 752).
} 
piece by two infertility doctors from the infertility clinic of the Finnish Family Federation. They argued for permitting surrogacy since, with proper safeguards in place, it had proven to be a beneficial form of assisted reproduction (Vilska \& Söderström-Anttila 2002).

For the first time, there was a shift on the issue of eligibility. The working party proposed that a single or lesbian woman could be eligible for fertility treatment on two conditions: 1) she was involuntarily childless (i.e. infertile) and 2) the man whose gametes were used in the fertility treatment (i.e., the donor and biological father) had consented to the treatment with the knowledge that he may later be declared, on the basis of his consent, to be the child's legal father. This was a major change from earlier proposals, which had explicitly refuted the establishment of a legal relationship between the donor and the child. If paternity, in accordance to the 1998 proposal, were established at the request of the mother, the biological father, or the child him or herself upon reaching the age of 15 , all the rights and responsibilities of legal parentage would follow.

The second eligibility criterion was formulated to satisfy the Ministry of Justice's requirement that the legal status of a child born to a single woman or to a lesbian couple be the same as that of a child born as a result of natural procreation, i.e., that the child have a legal father. This requirement accorded with the fundamental position held by the Ministry throughout the two decades of law drafting - that the welfare of the prospective child be safeguarded by the legislature since the child is unable to look after his or her own interests.

The same eligibility criterion was criticized by feminist commentators and members of the Green Party, among others. They argued that it would effectively deter single or lesbian women from using assisted reproduction to become parents. The Finnish Medical Association, on the other hand, opposed the provision giving the child the right to learn the identity of the donor, mainly out of fear of diminishing the donor pool. Furthermore, physicians in general were averse to government regulation on assisted reproduction. Over time, however, physicians changed their position, beginning to favor legislation for a number of reasons. First, the lack of regulation had caused a partial standstill in the provision of assisted reproduction services; second, the lack of regulation was perceived to be a source of embarrassment in the international arena; and third, there was a genuine need for authoritative legal guidance. Infertility doc- 
tors were reluctant to assume the role of a gatekeeper as to who should have access to assisted reproduction and under what conditions (Malin \& Burrell 2004, 86).

Since the Minister of Health and Social Services,61 the Green Party minister in the governmental coalition, objected to the proposition regarding single and lesbian women, the 1998 proposal was removed from the process. In May 2001 in negotiations held between the Minister of Justice and the Minister of Health and Social Services, it was decided that the proposal was to be returned to the officials at the Ministry of Justice and Ministry of Social Affairs and Health for further work. In the spring of 2002, the required modifications were finalized and, on June $5^{\text {th }} 2002$, The Government Proposal for the Act on the Use of Gametes and Embryos in Fertility Treatment and the Amendment to the Paternity Act (HE 76/2002) was submitted to the Eduskunta.

During the first months of 2002 the new proposal was subjected to intense media scrutiny which focused on the provision of fertility services to single women and lesbian couples and, in particular, on the issue of paternity. Some of the reporting helped to create the misperception that any sperm donor could end up as the legal father of a child born as a result of his donation. Because of this, in an exceptional move to attempt to clarify the issue, the Minister of Justice issued a press release in March 2002 (Oikeusministeriö 2002) giving assurances that a sperm donor could never become a legal father solely on the basis of his donation. Unfortunately, the press release added to the already intense attention given to the provision of services to single women and lesbian couples. This had the effect of diverting attention from the core issue, the very purpose of the proposal, which was the creation of a legal framework for infertile couples to be able to have children with the aid of assisted reproductive technologies.

After the preliminary debate in the Eduskunta, the proposal was referred to the Legal Affairs Committee in June 2002. The Committee gave

\footnotetext{
${ }^{61}$ There are two Ministers in the Finnish Ministry of Social Affairs and Health. Minister of Social Affairs and Health is in charge of legislation and planning related to social protection, unemployment security, pharmaceutical issues, and supervision of private insurance as well as issues related to gender equality and occupational safety and health. Minister of Health and Social Services is responsible for legislation and planning related to primary care and specialized health care, social welfare and social services, rehabilitation, health promotion, preventive social action, and environmental health (www.stm.fi 13.9.2005).
} 
its report (LaVM 29/2002 vp) in February 2003, having made two significant changes to the proposed act. First, upon reaching the age of 18, every donor-conceived child, without exception, would have the legal right to learn the identity of the donor. Any other outcome, according to the Committee, would violate the child's constitutionally guaranteed right to privacy. As regards the issue of access to donor information, the Legal Affairs Committee was in agreement with the Constitutional Law Committee, which stated in its opinion that donor anonymity would contradict the constitutional protection of privacy: "It would be problematic if authorities had information about an individual's origin while the individual himself or herself could not access that information” (PeVL 59/2002 vp). Second, only married or cohabiting heterosexual couples would be eligible for fertility treatment. For its decision to exclude single women and lesbian couples from the provision of fertility services, the Legal Affairs Committee offered a two-fold explanation. First, a legislative outcome that allowed the birth of fatherless children would seriously undermine the importance of fatherhood as a cultural and social institution. Second, the requirement that every child has two parents, a mother and a father, falls in line with the single most important principle of the almost two decades of law drafting - the rights and interests of the prospective child must be safeguarded.

At this point, the government requested that the bill be referred to the Grand Committee of Parliament hoping that the Grand Committee would undo the changes that the Legal Affairs Committee had made on the eligibility criterion. A referral to the Grand Committee would have been a highly unusual measure, however, and the majority of MPs voted against it, albeit by a narrow margin of only six votes. The vote signaled the clear possibility that, if allowed to vote on it, the Eduskunta would approve the proposal as amended by the Legal Affairs Committee. This prospect was unacceptable to the government, which during a meeting on February $11^{\text {th }}$ 2003 decided to withdraw its proposal from the Eduskunta.

The decision of the Legal Affairs Committee took lawmakers by surprise. The long labored compromise in the rainbow coalition was expected to practically guarantee the approval of the bill as proposed by the government. The unpredictability of parliamentarians unleashed from party discipline does not hold great promise for approval of the next government proposal either as pointed out by an official at the Ministry of 
Justice: "Since the government is a majority government we thought that the proposal would go through unaltered or at least mostly unaltered. But it didn't. And this only demonstrates that one can't know beforehand about issues that are of such fundamental nature and so close to each person's ethical convictions."

The next attempt to introduce a government proposal to the Eduskunta is expected by the end of 2005. Despite the division of opinions on the issue at the Eduskunta, ${ }^{62}$ the Ministry of Justice is planning on introducing a bill, which would allow infertility treatment also for single women and lesbian couples (Turun Sanomat 24.7.2005, Helsingin Sanomat 16.9.2005).

The failure to enact comprehensive ART legislation places Finland in a policy designing category called designing by non-decision (Rothmayr et al. 2004, 250). In this regard, Finland shares some important similarities with Belgium, another European country that has not passed a specific law on ART. In Belgium, the absence of comprehensive legislation is partly a result of the well-organized interest of the medical community and the lack of group pressure among infertility patients (Schiffino \& Varone 2004, 22). In Finland, the opposition by the medical community to government regulation has contributed to the present state of nondecision. Political scientists Nathalie Schiffino and Frédéric Varone describe Belgium as "a bioethical paradise" because of the minimal ART regulation and the substantial autonomy for the practitioners. This notwithstanding Belgium, very much like Finland, has avoided the kinds of pitfalls that produced an ultra-restrictive ART legislation in Italy. Finnish infertility doctors have refrained from taking advantage of the absence of ART legislation believing that any recklessness would almost certainly backfire. Their constraint seems to have worked so far.

\footnotetext{
${ }^{62}$ According to a survey published in April 2005 by Finnish television news Nelosen uutiset, almost 50 per cent of Finnish parliamentarians would allow infertility treatments for single women. About 40 per cent of the MPs who responded to the survey would allow infertility treatments for lesbian couples. The strongest opposition to single and lesbian women's access to assisted reproduction came from the Christian Democrats. Representatives from the Left Alliance and the Greens were the most permissive ones with regard to this issue (www.helsinginsanomat.fi/tuoreet/artikkeli/tulosta/1101979155794 15.4.2005).
} 


\section{Conclusion}

Despite the present divergence of ART policies in the Nordic countries, there have been sporadic attempts to harmonize Nordic law in the field. The first such attempt dates back to May 1948 when the Danish Ministry of Justice established a committee to investigate whether there was a need to regulate assisted fertilization by law (Betænkning 29/1953). Soon after the establishment of the Danish committee, a similar committee was set up in Sweden by the Swedish Ministry of Justice. The two committees met in Stockholm in December 1948 to explore opportunities for Nordic cooperation in the area. An observer from Norway participated in the meeting with the result that the Norwegian Ministry of Justice established a similar committee in January 1950 (Betænkning 29/1953, 5). Around that time officials from the Finnish Ministry of Justice expressed an interest in taking part in the collaboration and, in the course of that year, the Finnish Ministry of Justice set up the fourth and final Nordic committee to look into the legal issues connected to artificial insemination (Betænkning 29/1953, 5). The collaboration did not include representatives from Iceland, presumably for the reason that artificial insemination was not practiced in the country at the time.

Although four reports were published by the mid-1950s, none of them resulted in legislative action in any of the four countries. The Swedish Insemination Committee mentioned the committee report briefly in its 1983 report saying only that "it did not lead to legislation" (SOU 1983:42, 13). The first Finnish ART working party made a similar remark in its 1984 report (Lääkintöhallituksen työryhmä 1984, 3). An interviewee from Finland commented on the 1955 report, saying that "the report was buried quietly because, at the time, it was not considered appropriate to discuss such matters publicly.” 
The Nordic harmonization of ART legislation was next considered in the Nordic Council in the 1980s. The issue came up in the Council in 1984 at the initiative of five members from Finland, Denmark, and Sweden who proposed the Nordic Council to recommend that the Nordic Council of Ministers investigate how to unify Nordic legislation with regard to artificial insemination (Medlemsförslag A 694/j, 28.9.1984). In its $34^{\text {th }}$ session in 1986 the Nordic Council made such a recommendation to the Nordic Council of Ministers (Rekommendation 31/1986). The Council of Ministers however stated that, since all the Nordic countries had either started a policy designing process or, in the case of Norway and Sweden, had already completed such a process and passed a law, it was unlikely that unity in the area could be reached (The Nordic Council Protocol 1987, 1275-1276).

Almost four decades after the first harmonization attempt, the Federation of Scandinavian Societies of Obstetrics and Gynaecology established an ART working group, the Nordic Committee on Assisted Reproduction, "to coordinate ART practices in the different Nordic countries, to set up ART guidelines to guarantee medical and ethical excellence in the application of this new technology, to approach politicians from a common Nordic ART platform and to work for a sound legislative consensus to the benefit of infertile couples in these countries" (Hazekamp 1996, 200). The work of that committee did not lead to any tangible results, either.

After five decades of intermittent attempts, the Nordic countries still have very different policies in the field of assisted reproduction. What is the nature of these differences and how did they come about?

\section{Policy Design}

ART policy designs in general can be understood as falling along two dimensions according to the extent to which they intervene in the autonomy of the medical community and the extent to which they limit access for the beneficiaries. Autonomy refers to the amount of freedom that doctors and researchers enjoy either to practice ART or to conduct related research. ART policies also target infertile couples and other potential clients, or beneficiaries, who may wish to use infertility services to be- 
come parents. Access thus refers to the extent to which potential users of ART may take advantage of these services (Goggin et al. 2004, 4).

Public policies or policy designs can be compared along the dimensions of autonomy and access, using a permissive - restrictive continuum that, according to Goggin et al., "characterizes the governance of much science policy in general and biomedical policy in particular" (Goggin et al. 2004, 5). A permissive policy design grants wide access and a high level of autonomy; a restrictive design results in a limited access and a limited amount of self-regulation; and an intermediate design falls in between.

In the absence of comprehensive ART legislation, Finland belongs to the permissive category by default. The practitioners of ART in Finland are able to use the widest range of techniques among the Nordic countries, including egg and embryo donation, surrogate motherhood, and stem cell research. Since much of the provision of ART in the country is left to the self-regulation of the medical community, the level of autonomy is high. Furthermore, infertility services are accessible for single women and lesbian couples, making the level of access high as well.

Denmark allows egg donation, stem cell research, and preimplantation diagnosis. The autonomy of medical practitioners of ART is thus quite high. The Danish Act on Artificial Fertilization limits access to infertility services to heterosexual couples, but single women and lesbian couples have access via what could be characterized as a loophole in the Act. In practical terms, then, the provision of ART in Denmark is fairly liberal. However, since the level of access to infertility services is only medium de lege, the country belongs to the intermediate category of policy design.

The policy design in Iceland falls into the intermediate category. Embryo donation and stem cell research are not permitted in Iceland and access is restricted to heterosexual couples. However, this may change soon as the Icelandic government appointed an expert committee in October 2005 to prepare a bill on stem cell research. In addition, an initiative for granting access to infertility treatments for lesbian couples has been forwarded recently.

On the other hand, due to the double track policy adopted in the Icelandic Act on Artificial Fertilization, gamete donors may choose whether they wish to donate anonymously or non-anonymously and the recipient 
couples have the option of deciding between anonymous and identifiable donors. However, in the case of donor sperm the choice is merely theoretical since all donor sperm is imported from Denmark where donor anonymity is protected by law. Iceland's intermediate policy design results from a medium level of autonomy and a medium level of access.

The Norwegian Act on the Medical Use of Biotechnology of 2003 is the most stringent in the Nordic region, placing the country in the restrictive category. The Act bans several techniques, including egg and embryo donation and embryo research, placing Norway at a low level of autonomy. Access is limited to heterosexual couples and can be characterized as medium. Whereas Finland has yet to come up with a policy design and Iceland and Denmark are still in their first generation of ART policies, Norway has responded to the rapid developments of assisted reproductive technologies with several re-designs of its ART policies. Each of these redesigns has consolidated Norway's restrictive stance on assisted reproduction.

Similarly to Norway, Sweden has entered its third generation of ART policies through several re-designs. In contrast with the Norwegian ART policy design, however, the Swedish ART policy design has undergone a gradual transformation from a fairly restrictive design to a permissive one. Both autonomy of the medical practitioners and access to ART are rather high in the current Swedish legislation. Most ART techniques are allowed in the Swedish Act on In Vitro Fertilization of 1988. The only remaining restriction is the ban on embryo donation. Although surrogate motherhood is not explicitly prohibited in the Swedish law, surrogacy is not practiced in the country. Since July $1^{\text {st }} 2005$ lesbian couples, whether cohabiting or living in a registered partnership, are allowed by law to have access to infertility services.

\section{The Timing of Decision-making}

In addition to the divergence in the policy design, the timing of decisionmaking varies significantly among the Nordic countries. Essentially there have been two waves of decision-making in the field of ART. Norway and Sweden responded early to the invention of in vitro fertilization. Both 
countries designed their first generation of ART policies in the 1980s, resulting in restrictive policies.

The second wave of decision-making took place in the 1990s when Iceland and Denmark passed their respective laws. In vitro fertilization was introduced in clinical practice in Iceland in the early 1990s, almost a decade later than in the other Nordic countries, which explains the timing of decision-making in that country. The initial response to the new reproductive technology in Denmark appears to have been to view it as a primarily medical issue, best left to the self-regulation of the medical community. As a result, the practice of ART was quite liberal in the country prior to the 1997 Act. It seems that two events in the mid-1990s triggered a change towards more restrictive policies: first, the highly publicized scandals that occurred in the Danish private infertility clinics in 1993 and, secondly, the 1995 report on assisted reproduction by the Danish Council of Ethics that brought attention to the ethical aspects of ART. The 1997 Act on Artificial Fertilization curtailed some of the most liberal elements of the practice of ART in Denmark, but because of the rather high level of autonomy and the de facto high level of access, the practice of ART in the country is fairly liberal. The third wave is yet to come as Finnish lawmakers prepare for a second round of legislative effort in the Finnish Parliament towards the end of 2005.

The timing of decision-making is of relevance in this context because of the qualities that are generally attributed to the 'natural' progress of the appropriation process: attitudes tend to become more liberal over time. It has been hypothesized that the integration of new technologies takes place gradually as acceptance and familiarization accompany diffusion and increased use (Jamison 2002, 99). In their book entitled "Infertility in Women” (1966), Sophia Kleegman and Sherwin Kaufman describe the evolution of societal attitudes towards various inventions, such as contraception or assisted reproduction, that have taken place in the field of sex: "Any change in custom or practice in this emotionally charged area has always elicited a response from established custom and law of horrified negation at first; then negation without horror; then slow and gradual curiosity, study, evaluation, and finally a very slow but steady acceptance” (Kleegman \& Kaufman 1966, 178).

For such reasons Robert Lee and Derek Morgan recommend that governments resist the urge to legislate at the first available opportunity. 
They write that "government sometimes acts wisely in refusing or failing to regulate (by law) in order to allow debate and discussion to proceed, and perhaps to encourage some moral consensus to emerge" (Lee \& Morgan 2001, 267).

With one exception, the hypothesis of increasing acceptance seems to apply to the Nordic countries. The early legislators, Norway and Sweden, implemented a restrictive design at the time or soon after the introduction of in vitro fertilization in the clinical practice. It appears that the restrictive design was indeed a response of "negation." The second wave of legislators, Iceland and Denmark, had both benefited from a fairly lengthy period of medical practice in assisted reproduction. The stage of "diffusion and increased use" produced an intermediate design in Iceland. Denmark not only legislated somewhat later than Iceland but also had started to experiment with ART several years earlier than Iceland, which may explain its slightly more permissive design. Moreover, Sweden has re-designed its policies several times over a span of two decades. The slow but sure liberalization of the Swedish ART legislation matches with the hypothesis of increasing acceptance. A political agreement on the liberalization of assisted reproduction has been reached recently in Iceland. It appears that it has the support of the general public. If Finland follows the pattern of increasing acceptance it will eventually adopt a permissive ART policy design. However, the events in the Finnish Parliament in 2002 demonstrated that the appropriation process is subject to contingencies of all sorts and is therefore less predictable than suggested above. Norway certainly provides a powerful counter argument to the thesis of a linear process of acceptance. Norway's restrictive stance has survived two decades of diffusion and familiarization, and shows no signs of changing. ${ }^{63}$

\section{Actor Beliefs}

In general, actors favoring permissive policy designs in the field of ART believe that biomedical and scientific progress is beneficial for humanity

\footnotetext{
${ }^{63}$ However, in June 2005 the Norwegian Parliament instructed the government to introduce an amendment to the Act on the Medical Use of Biotechnology, which would permit a limited use of PGD and embryo research (Vedtak 443/2005).
} 
and that a new treatment method should be made available as soon as scientific criteria indicate that it is advisable. They also believe that state intervention should be kept at a minimum (Rothmayr et al. 2004, 233). In the early phases of the policy designing process in Finland the medical community believed that state regulation would deter progress in the field of assisted reproduction. It therefore exerted influence successfully to block legislation. More recently, however, the absence of ART legislation seems to have resulted from a non-congruence of interests and beliefs among the relevant actors. This non-congruence has manifested within the government as a disagreement between the Minister of Justice and the Minister of Health and Social Services as well as between the government and the Parliament with the result that the government withdrew its proposal from the Parliament in 2002.

Iceland exhibits some of the core elements of the policy designing type called designing by experts: congruence of interests and beliefs among the important actors, a favored and uninterrupted designing process, and a substantial design output according to the dominant beliefs of the most resourceful actors. Although there was a broad consensus that ART was practiced more than capably in the country, the necessity of comprehensive state regulation operated as an institutionalized norm that was taken for granted by all involved actors (Rothmayr et al. 2004, 244).

Supporters of restrictive design are more skeptical about biomedical and scientific progress and believe that the risks and disadvantages are greater than the potential benefits (Rothmayr et al. 2004, 233). They call for the state to set strict limits on professional autonomy and to allow access only to a narrow circle of beneficiaries. In Norway the Christian Democratic Party has been a resourceful and influential actor. It has been able to ensure that its core values dominate the priority setting in the ART policy designing process. This actor profile coincides with the policy designing type that can be characterized as designing by party politics. However, while the Christian Democrats have occupied the center stage in the Norwegian ART policy-making, they have been backed by a segment of the country's environmental movement. This is not a uniquely Norwegian phenomenon. A similar actor configuration led to a restrictive ART policy design in Germany (Rothmayr \& Ramjoué 2004). Although an occasional combination of "blue" or traditionalist resistance and "green" or modernist resistance to the different applications of biotech- 
nology has been observed on the basis of Eurobarometer data (see Rothmayr et al. 2004, 233), this does not appear to be the case in the Nordic countries, with the exception of Norway. In fact, interest groups in general have not been particularly active in ART policy designing process in the Nordic countries. It is difficult to determine whether their absence results from a fragmentation of beliefs and interests within the interest groups or whether ART regulation has not represented a priority for them. The only interest group that appears to have been moderately active in the Nordic countries is the gay and lesbian movement, which has exerted substantial political pressure on policymakers to expand access to ART.

It appears that the gradual liberalization of assisted reproductive technologies in Sweden is, to some extent, a by-product of the creation of an industry-friendly regulatory environment to promote biotechnological innovation and commercialization in the country. The transition from the restrictive ART policy design to the permissive one has been led by the governing Social Democratic Party with relatively little input from the medical community. This is partly the result of the fact that the physicians' bargaining power is reduced by internal divisions. The medical profession is represented by two organizations in Sweden: the Swedish Society of Medicine (SSM), which is the scientific organization of the medical community; and the Swedish Medical Association (SMA), the professional organization with trade union status. Even though the two organizations have different responsibilities, they can end up in a competitive situation in certain medical policy issues (Garpenby 1999, 8). The inability of the medical community to act collectively due to internal divisions and the competitive relationship between the SSM and SMA has boosted the already substantial authority of the National Board of Health and Welfare. Since the Ministry of Health and Social Affairs does not have the institutional resources to direct its agencies in detail, the Board has a great deal of freedom with respect to policy formulation as well as policy implementation in Swedish health care (Garpenby 1999, 6). Moreover, according to Garpenby, in its relationship with the medical profession the Board has long relied on a strategy whereby it assures its legitimacy by means of participation by medical practitioners, but only by hand-picked ones whose views comply with those of the Board (Garpenby 1999, 14). 
The Danish policy designing process has been characterized by the somewhat ambiguous role of the Danish Council of Ethics. On the one hand, the Act on the Danish Council of Ethics mandates the Council to give advice and information on ethical issues to the Danish Parliament, the public authorities, and the general public. The Council's work has been of formative significance in conceptualizing assisted reproduction as an ethical and social issue, not merely as a medical issue. This reconceptualization of assisted reproduction seems to have contributed to the curtailing of some of the most liberal elements of the provision of ART by the 1997 Act on Assisted Fertilization. On the other hand, the views of the Council of Ethics itself with regard to assisted reproduction have evolved in a more permissive direction over the years. Those views now stand at odds with the more restrictive views of the Danish medical community and of the present government coalition of Liberals and Conservatives.

\section{Arena of Law-drafting}

The arena where major elements of a policy are actually crafted may itself be constitutive to the policy designing process. The arena, in and by itself, often influences the outcome of the designing process through various mechanisms. According to Goggin et al., the institutional context influences the amount and distribution of information available to actors, the amount and distribution of power and control available, and the costs and benefits to be derived from alternative decisions (Goggin et al. 2004, 10-11). Moreover, each arena is defined by a specific set of institutional rules and norms that shape the behavior, the expectations, and the motives of the actors operating in that particular arena.

The ideal type of the pre-parliamentary ART policy designing process in the Nordic countries was that it takes place either in the Ministry of Justice (or equivalent) or in the Ministry of Health (or equivalent). The choice between the two ministries would appear to depend on the prior perception of ART as either primarily a medical or health care issue (in which case the chosen arena was the Ministry of Health) or primarily a legal and ethical issue with important consequences for family law and ethics (in which case the chosen arena was the Ministry of Justice). In 
Denmark and Norway the chosen arena was the Ministry of Health whereas in Iceland, Finland, and Sweden the chosen arena was, for the most part, the Ministry of Justice. The way the designing process took shape from then on is fairly consistent with the characteristics of the chosen arena, with the exception of Norway.

In the cases of Iceland and Sweden, substantial attention was given to the legal rights and responsibilities of the different parties - specifically those of the child born as a result of the use of assisted reproduction - and the repercussions of ART to family law. In Denmark the emphasis on ART as a health care issue is clearly discernible although ethical issues have also received quite a lot of attention.

In Finland the law drafting has been led by the Ministry of Justice but in cooperation with the Ministry of Social Affairs and Health. In the most recent stages of the process, officials at the Ministry of Justice have worked on legislative drafts while officials at the Ministry of Social Affairs and Health have examined them. Furthermore, the Ministry of Justice has been in charge of issues that are pertinent to family law and ethics, deferring responsibility for issues strictly related to health care to the Ministry of Social Affairs and Health. Although the division of labor between the two ministries seems simple enough, simplicity has not always been the order of the day. One of the issues causing disagreement between the two ministries has been donor anonymity. Because of its strong commitment to the interests of the prospective child, the Ministry of Justice has opposed donor anonymity. The Ministry of Social Affairs and Health, on the other hand, has backed the medical community's view in the matter thus upholding donor anonymity. Despite the theoretically clear division of labor the Ministry of Social Affairs and Health has not constrained itself to strictly medical issues. The same blurring of responsibilities has occurred at the ministerial level. Even though the responsibility of ART policy designing process belongs to the Minister of Justice, the Minister of Health and Social Services has assumed a rather strong role in the field. The differences between the two ministers reflect some of the differences between the two ministries. In addition, the fact that the two ministers have come from different parties has added a political element to the divergence between the two ministries. These differences - the difference between the two arenas and the difference between the two actors - have contributed to the absence of ART policy design in Finland. 
Norway, again, seems slightly atypical when compared to its neighbors because, even though the ART policy designing process occurred within the Ministry of Health, ethical and legal issues have dominated the process in the country.

\section{The Broader Context}

The broader context of the policy designing process consists of external factors including scientific progress, public perceptions, media coverage, formative events, and other such factors that may influence the designing of policies (Goggin et al. 2004, 12-13).

The invention of IVF was considered a scientific breakthrough of such importance that it produced an almost immediate response from Nordic policy-makers when it became available in the region. In Iceland the ART policy designing process was in fact initiated before IVF was practiced in the country. Finnish policy-makers, in contrast, were relatively slow to respond: from the time of the birth of the first Finnish test-tube baby in 1984 it took three years before the first Ministry of Justice working group was given the task of drafting a comprehensive law proposal on assisted reproduction. However, the amount of time it took from the initial response to the actual adoption of policy in each country - and whether policies were designed at all - was determined by other factors. More recently, developments in human reproductive cloning and embryonic stem cell research have elicited similarly swift responses.

Past experiences can have a major impact on the place and salience of assisted reproduction on the governmental agenda (Rothmayr et al. 2004, 246). Among the Nordic countries Norway is the most evident case of the legacy of past experiences. The political struggle over abortion in the 1970s continues to reverberate in the Norwegian politics of assisted reproduction. The Christian Democrats, who have never accepted the liberalization of the abortion law, have embraced the issue of ART as an opportunity to carry on the battle for unborn human life. Moreover, the apparent distaste toward the idea of selection, sortering, in the country may testify to the impact of an experience even more distant in the Norwegian past - the eugenics movement in the first half of the $20^{\text {th }}$ century. Both of these past experiences are of course shared by all Nordic countries, but 
only in Norway they have strengthened significantly the influence of the Christian Democratic Party and other technology pessimists.

Formative events, whether scandals, scientific discoveries, or human interest stories, often receive extensive media attention, spark public debate, and may influence agenda-setting and the timing of decisionmaking. The medical scandals in Danish infertility clinics in 1993, for example, appear to have strengthened calls for stricter control over ART in the country. The "savior sibling" cases in Denmark and Norway pushed the policy development in a direction it might not have taken otherwise. A revision to the Swedish ART legislation to expand access to infertility services to lesbian couples was already under way when the Swedish media in 2001 reported on a legal case where a lesbian mother separated from her partner sought and won financial support for her child from the sperm donor. However, the case may have precipitated the adoption of the revision.

Policies adopted in neighboring countries can also influence the policy design. The Nordic countries have a long tradition of harmonization of legislation. The law-drafting process in each Nordic country routinely involves an investigation into the legislative situation in other countries, most importantly in the other Nordic countries. The legislation enacted and the experience gained in the neighboring countries are studied as a part of basic information collection, but the information thus gained can be used strategically by various actors for various goals. Since the policies adopted in other countries can be used selectively by way of presenting them either as models to be followed or failures to be avoided, lessondrawing across countries has no clear-cut impact on the choices made. Nevertheless, a certain degree of lesson-drawing across the Nordic countries did, in fact, take place in the ART policy domain. The Swedish Insemination Committee's argument against egg donation in its 1985 report and the subsequent prohibition on egg donation in the 1988 Act on In Vitro Fertilization makes an interesting case study. The rationale for banning egg donation in the report of the Insemination Committee was adopted in Norway and, even though the ban was revoked in Sweden in 2002, the Norwegian law continues to ban egg donation. The first Ministry of Justice ART working group in Finland studied closely the report of the Insemination Committee but, unlike its Norwegian counterpart, did not find it convincing. Instead, it recommended that egg donation be per- 
mitted for reasons of equality in health care. Thus, the same report had a quite different impact in two different neighboring countries.

Lastly, public perceptions may have an impact on policy design. Gaskell et al. (1998) suggest that policy processes have become increasingly sensitive to public opinion. However, while there is some evidence that public opinion influences policy designing (see, for example, Rothmayr et al. 2004), the interactions and causalities between the two are too complex to warrant any straightforward explanations or predictions. Gaskell et al. advice that a detailed examination of a whole host of variables be performed when studying the dynamics of public perceptions: "Understanding these interactions requires attending to factors visible on the institutional or societal level, as well as the individual level; the regulatory climate, not just specific regulations; media systems, not just specific messages; and social values, not just individual opinion” (Gaskell et al. 2003, 43). Unfortunately, with little survey data dealing directly with assisted reproduction in the Nordic countries, the issue of public perceptions is left outside the scope of the present study.

Complex social phenomena do not lend themselves to easy explanations. The socio-political appropriation of a new technology such as assisted reproduction is a multifarious and complicated process. This study has traced the ART policy designing process in the Nordic countries in an effort to find the factors that account for the variation of ART policies between the five countries. The study has found that the five Nordic countries have dealt with assisted reproduction over very different timescales and in very different ways. On the basis of this study it can most emphatically be concluded that there is no such thing as 'the Nordic policy on assisted reproduction'.

There are no simple explanations for the divergence in ART policies across the Nordic countries. By examining the policy design processes, this study has been able to identify a number of factors that have impacted the ART policy content in each Nordic country and thus underlie the diversity of policy designs. These factors have to do with the timing of decision-making, actor beliefs, the arena of policy-making, and a variety of issues connected to the broader context. Important as all these factors are in clarifying the picture of assisted reproduction in the Nordic countries, they do not capture the whole image. For instance, why did Denmark not adopt a more permissive ART policy design, given its long 
traditions of liberalism and progressiveness? Why do technology pessimists have such a stronghold on assisted reproduction in Norway? These and other such questions can only be explained by cultural differences that extend far wider and deeper than the technology itself. 


\section{References}

\section{Books and articles}

Albæk, Erik: Political Ethics and Public Policy: Homosexuals between Moral Dilemmas and Political Considerations in Danish Parliamentary Debates. Scandinavian Political Studies, Vol. 26, No. 3, 2003, 245-267.

Alvarez, Lizette: Arhus Journal: Spreading Scandinavian Genes, Without Viking Boats. The New York Times 30.9.2005.

Andersen, A. N., Gianaroli, L. and Nygren, K.G.: Assisted reproductive technology in Europe, 2000. Human Reproduction, Vol. 19, No. 3, 490-503, March 2004.

Andersen, Anders Nyboe, Westergaard, Hanne Brix \& Olsen, Jørn: The Danish in vitro fertilization (IVF) register. Danish Medical Bulletin, Vol. 46, No. 4, September 1999, 357-360.

Baldwin, John and Davies, Gwynn: Empirical Research in Law. In Peter Cane and Mark Tushnet (eds.): The Oxford Handbook of Legal Studies. Oxford University Press, Oxford 2003. Bauer, Martin: Controversial medical and agri-food biotechnology: a cultivation analysis. Public Understanding of Science 11 (2002) 93-111.

Bauer, Martin, Durant John and Gaskell, George: Biology in the public sphere: a comparative review. In John Durant, Martin W Bauer and George Gaskell (eds.): Biotechnology in the Public Sphere: A European Sourcebook. Science Museum, London 1998.

Bleiklie, Ivar: Legislation for protection: Why Norway designed restrictive policies in the field of ART. In Ivar Bleiklie, Malcolm L. Goggin and Chri- stine Rothmayr (eds.): Comparative Biomedical Policy: Governing assisted reproductive technologies. Routledge, London and New York 2004.

Bleiklie, Ivar, Goggin, Malcolm L. and Rothmayr Christine (eds.): Comparative Biomedical Policy: Governing assisted reproductive technologies. Routledge, London and New York 2004. Blyth, Eric and Landau, Ruth (eds.): Third Party Assisted Conception Across Cultures: Social, Legal and Ethical Perspectives. Jessica Kingsley Publishers, London 2004.

Blyth, Eric and Landau, Ruth: Introduction. In Eric Blyth and Ruth Landau (eds.): Third Party Assisted Conception Across Cultures: Social, Legal and Ethical Perspectives. Jessica Kingsley Publishers, London 2004.

Bryld, Mette: The Infertility Clinic and the Birth of the Lesbian: The Political Debate on Assisted Reproduction in Denmark. The European Journal of Women's Studies, Vol. 8(3): 299-312, 2001.

Bygdeman, M.: The Swedish Insemination Act. Acta Obstet Gynecol Scand 1991;70: 265-266.

Damgaard, Erik: Developments in Danish Parliamentary Democracy: Accountability, Parties and External Constraints. Scandinavian Political Studies, Vol. 27, No. 2, 2004,115-131. Daniels, Ken: The Swedish Insemination Act and Its Impact. Aust. and N.Z. Journal of Obstetrics and Gynaecology 1994; 34; 4: 437.

Daniels, K. \& Lalos, O.: The Swedish insemination act and the availability of donors. Human Reproduction, Vol. 10, No. 7 pp. 1871-1874, 1995. 
The Danish Board of Technology: Consensus Conference on Infertility. Final Document. Conclusions of the Lay Panel at the Consensus Conference on Infertility, 29 October - 1 November 1993 at the Danish Parliament. www.tekno.dk.

The Danish Council of Ethics: Assisted Reproduction: A report. The Danish Council of Ethics 1995.

The Danish Council of Ethics: Ethical problems concerning assisted reproduction. Part II: Anonymity and selection in the context of sperm donation. Report. The Danish Council of Ethics 2002.

The Danish Council of Ethics: 2002

Annual Report. The Danish Council of Ethics 2003.

Dolley, Margaret: Controls urged for Denmark's private infertility clinics. British Medical Journal 1993, Sep 11; 307 (6905):643-644.

Durant, John, Bauer, Martin W. and Gaskell, George (eds.): Biotechnology in the Public Sphere: A European Sourcebook. Science Museum, London 1998.

Edvinsson, Alf et al.: Givarinsemination vid manlig infertilitet - slut på en epok? Läkartidningen, Vol. 87, Nr. 21, 1871-1872, 1990.

Folcker, Lotta: Hiv-tester försenar äggdonationer. Dagens Nyheter $21 \mathrm{dec}$ 2002. www.dn.se/NDet/jsp/polopoly. jsp?d=147\&a=90218 22.9.2005.

Fonnest, Isabel de la Fuente, Søndergaard, Finn, Fonnest Gert \& VedstedJacobsen, Agnete: Attitudes among health care professionals on the ethics of assisted reproductive technologies and legal abortion. Acta Obstetricia et Gynecologica Scandinavica, 79 (2000), 49-53.

Garpenby, P.: Resource Dependency, Organised Medicine and the State: Quality Control in Sweden. Social Science and Medicine, 49, 405-424, 1999.
Gaskell, George, Allum, Nick and Stares, Sally: Europeans and Biotechnology. Eurobarometer 58.0. $2^{\text {nd }}$ Edition: March $21^{\text {st }} 2003$. A report to the EC Directorate General for Research from the project 'Life Sciences in European Society’ QLG7-CT-1999-00286. Directorate General, Public Opinion Analysis Unit 2003.

Gaskell, George, Bauer, Martin and Durant, John: The representation of biotechnology: policy, media and public perception. In John Durant, Martin W. Bauer and George Gaskell (eds.): Biotechnology in the Public Sphere: A European Sourcebook. Science Museum, London 1998.

Goggin, Malcolm L. et al.: The comparative policy design perspective. In Ivar Bleiklie, Malcolm L. Goggin and Christine Rothmayr (eds.): Comparative Biomedical Policy: Governing assisted reproductive technologies. Routledge, London and New York 2004.

Gottlieb, Claes, Lalos, Othon and Lindblad, Frank: Disclosure of donor insemination to the child: the impact of Swedish legislation on couples' attitudes. Human Reproduction, Vol. 15, No. 9, 2052-2056, September 2000.

Hagenfeldt, Kerstin: Givarinsemination behandlingsmetod i kris. Läkartidningen, Vol. 87, Nr. 21, 1849-1850, 1990. Hazekamp, J.T.: Current differences and consequences of legislation on practice of assisted reproductive technology in the Nordic countries. Acta Obstetricia et Gynekologica Scandinavica 75 (1996), 198-200.

Hazekamp, Johan \& Hamberger, Lars: Regulation of Artificial Reproductive Technology: The Nordic Experience. In Peter R. Brinsden (ed.): Textbook of In-Vitro Fertilization and Assisted Reproduction. 3rd Edition. Taylor \& Francis, London 2005.

Häyrinen-Alestalo, Marja \& Kallerud, Egil: Introduction: Towards a Biotech 
Society - Nordic Perspectives. In Marja Häyrinen-Alestalo and Egil Kallerud (eds.): Mediating Public Concern in Biotechnology: A map of sites, actors and issues in Denmark, Finland, Norway and Sweden. NIFU Rapportserie 2/2004, Oslo 2004.

Jamison, Andrew: From innovation to appropriation: On the politics of technoscience. In Focus on biotechnology: Issues related to $\mathrm{R} \& \mathrm{D}$ in biotechnology: Denmark in a comparative perspective. The Danish Institute for Studies in Research and Research Policy 2002/2.

Jamison, Andrew \& Lassen, Jesper: Assessing Genetic Technologies in Denmark. In Marja Häyrinen-Alestalo \& Egil Kallerud (eds.): Mediating Public Concern in Biotechnology: A map of sites, actors and issues in Denmark, Finland, Norway and Sweden. NIFU Rapportserie 2/2004, Oslo 2004.

Kallerud, Egil: The Ambiguity of Progress - Biotechnology in Norway. In Marja Häyrinen-Alestalo \& Egil Kallerud (eds.): Mediating Public Concern in Biotechnology: A map of sites, actors and issues in Denmark, Finland, Norway and Sweden. NIFU Rapportserie 2/2004, Oslo 2004.

Keohane, Robert, King, Gary and Verba, Sidney: Designing Social Inquiry: Scientific Inference in Qualitative Research. Princeton University Press, Princeton 1994.

Kleegman, Sophia and Kaufman, Sherwin: Infertility in Women: Diagnosis and Treatment. F.A. Davis Company, Philadelphia 1966.

Koch, Lene: Hvad skal vi med reagensglasbefrugtning? Et forsøg på helhedsvurdering. Social kritik 16/91, 46-55.

Kurki-Suonio, Kirsti: Äidin hoivasta yhteishuoltoon: lapsen edun muuttuvat oikeudelliset tulkinnat: oikeusvertaileva tutkimus. Suomalainen lakimiesyhdistys, Helsinki 1999.
Lee, Robert \& Morgan, Derek: Human Fertilisation \& Embryology: Regulating the Reproductive Revolution. Blackstone Press Limited 2001.

Lüttichau, Ingrid: 'We Are Family': The Regulation of 'Female-only' Reproduction. Social \& Legal Studies, Vol. 13(1): 81-101, 2004.

Malin, Maili \& Burrell, Riitta: Finland: Unregulated Practices, Familiarity and Legality. In Eric Blyth and Ruth Landau (eds.): Third Party Assisted Conception Across Cultures: Social, Legal and Ethical Perspectives. Jessica Kingsley Publishers, London and New York 2004.

Nielsen, Linda \& Faber, Berit: Ethical principles in European regulation of biotechnology - possibilities and pitfalls. Biotik, Copenhagen 2002.

Nilsson, Annika: Barn till varje pris? Femte skriften i vetenskapsakademiens serie om Människan och den nya biologin. Bokförlaget Atlantis AB, Lund 1996.

Ragin, Charles: The comparative method: moving beyond qualitative and quantitative strategies. University of California Press, Berkeley 1987.

Rothmayr, Christine et al.: Comparing policy design across countries: What accounts for variation in ART policy? In Ivar Bleiklie, Malcolm L. Goggin and Christine Rothmayr (eds.): Comparative Biomedical Policy: Governing assisted reproductive technologies. Routledge, London and New York 2004.

Rothmayr, Christine and Ramjoué, Celina: Germany: ART policies as embryo protection. In Ivar Bleiklie, Malcolm L. Goggin and Christine Rothmayr (eds.): Comparative Biomedical Policy: Governing assisted reproductive technologies. Routledge, London and New York 2004.

Schiffino, Nathalie and Varone, Frédéric: Belgium: a bioethical paradise? In 
Ivar Bleiklie, Malcolm L. Goggin and Christine Rothmayr (eds.): Comparative Biomedical Policy: Governing assisted reproductive technologies. Routledge, London and New York 2004.

Skogstrøm, Lene: Ukjent antall "designerbarn”. Aftenposten 12.3.2004. www.aftenposten.no/helse/article7520 42.ece 19.9.2005.

Skovmand, Kaare: Danish fertility bill sparks debate. The Lancet, Vol. 347, February 17, 1996, 462.

Skovmand, Kaare: First-ever fertilization bill passed in Denmark. The Lance, Vol. 349, June 7, 1997, 1678.

Straumsheim Grønli, Kristin: Fem babyer sortert for å redde søsken. www.forskning.no/Artikler/2004/mai/ 1084188795.72/artikkel_print 19.9.2005.

Söderström-Anttila, Viveca et al.: Experience of in vitro fertilization surrogacy in Finland. Acta Obstetricia et Gynecologica Scandinavica 81, 747-52, 2002.

Tännsjö, Torbjörn: Klonade barn bör hälsas med glädje. Dagens Nyheter 4 jan 2003.

Vilska, Sirpa \& Söderström-Anttila, Viveca: Sijaissynnytyksiä ei tule kieltää. Helsingin Sanomat 14.4.2002.

Women's Health Weekly: Assisted Reproduction: Europe's healthcare systems support trend for quality and quantity in ART. Jul. 31, 2003, 12.

Zachary, G. Pascal: A most unlikely industry finds it can't resist globalization's call: Exporting human sperm is a fast-growth business, banks in Denmark, U.S. find. The Wall Street Journal Jan 6, 2000.

\section{Official Documents}

\section{Denmark}

Betænkning nr. 29 om en særlig lovgivning om kunstig befrugtning. Afgivet af det ved justitsministeriets skrivelse af 29. maj 1948 nedsatte udvalg. København 1953.

Det Etiske Råd: Svar på henvendelse fra Indenrigs- og Sundhedsministeriet: Mulige ændringer af loven om kunstig befrugtning. Afgivet den 4. april 2005. www.etiskraad.dk/sw5490.asp 30.8.2005.

Indenrigsministeriet: Fremskridtets pris. Rapport afgivet af indenrigsministeriets udvalg om etiske problemer ved ægtransplantation, kunstig befrugtning og fosterdiagnostik. Indenrigsministeriet 1984 .

\section{Finland}

HE 76/2002. Hallituksen esitys Eduskunnalle laeiksi sukusolujen ja alkioiden käytöstä hedelmöityshoidossa ja isyyslain muuttamisesta, vp 5.6.2002.

LaVM 29/2002 vp - HE 76/2002 vp. Lakivaliokunnan mietintö 29/2002 vp. Hallituksen esitys laeiksi sukusolujen ja alkioiden käytöstä hedelmöityshoidossa ja isyyslain muuttamisesta.

Lääkintöhallituksen työryhmä, Inseminaatio. Lääkintöhallituksen työryhmien mietintöjä 8/1984. Helsinki 1984.

Oikeusministeriö, Oikeusministeri Johannes Koskinen: Oikaisuja hedelmöityshoito-uutisointiin. Oikeusministeriön tiedotus 13.3.2002. www.om.fi 13.3.2005.

Oikeusministeriön työryhmä, Ehdotus Hallituksen esitykseksi Eduskunnalle laeiksi ihmisen keinotekoisista lisääntymismenetelmistä sekä isyyslain muuttamisesta. Oikeusministeriön työ- 
ryhmän mietintö, Lainvalmisteluosaston julkaisu 12/1988.

Oikeusministeriön työryhmä, Ehdotus Hallituksen esitykseksi Eduskunnalle laeiksi ihmisen keinoalkuisesta lisääntymisestä sekä isyyslain muuttamisesta. Oikeusministeriön työryhmän mietintö 18.12.1990.

Oikeusministeriön työryhmä, Sukusolujen ja alkioiden käyttö lääketieteellisessä hedelmöityshoidossa. Oikeusministeriön työryhmän mietintö 14.10.1997.

Oikeusministeriön työryhmä, Ehdotus Hallituksen esitykseksi Eduskunnalle laeiksi sukusolujen ja alkioiden käytöstä hedelmöityshoidoissa ja isyyslain muuttamisesta. Oikeusinisteriön työryhmän mietintö 23.10.1998.

PeVL 59/2002 vp - HE 76/2002 vp.

Perustuslakivaliokunnan lausunto 59/2002 vp. Hallituksen esitys laeiksi sukusolujen ja alkioiden käytöstä hedelmöityshoidossa ja isyyslain muuttamisesta.

STAKES, Hedelmättömyyshoitoja koskevien lakiesitysten kiirehtimiseksi. STAKES:n työryhmän ehdotus 14/1996.

\section{Iceland}

Frumvarp til laga um tæknifrjóvgun (184). Lagt fyrir Alpingi á 120. löggjafarpingi 1995. www.althingi.is/altext/ 120/s/0184. html 12.4.2005.

Magnússon, Árni: Ræður og greinar. Hinsegin dagar, 9.8.2005. www.felags malaraduneyti.is/radherra/raedur-oggreinar/nr/2013 10.10.2005.

Nefndarálit um frv. til l. um tæknifrjóvgun (819). Frá meiri hluta allsherjarnefndar (SP, VS, SighB, ÖJ, KPál, ÁRA, JónK). 120. löggjafarping 199596. www.althingi.is/altext/120/s/0819. html 12.4.2005.

Nefndarálit um frv. til l. um tæknifrjóvgun (824). Frá 1. minni hluta allsher- jarnefndar (G. Guðbjörnsdóttir). 120. löggjafarping 1995-96. www.althingi. is/altext/120/s/0824.html 12.4.2005.

Nefndarálit um frv. til l. um tæknifrjóvgun (841). Frá 2. minni hluta allsherjarnefndar (H. Jónsson). 120. löggjafarping 1995-96. www.althingi.is/ altext/120/s/0841.html 12.4.2005.

Reglugerð nr. 218/1987 um greiðslu læknishjálpar við glasfrjóvgun erlendis.

Skýrsla til dóms- og kirkjumálaráðherra frá eftirlitsnefnd með framkvæmd laga um tæknifrjóvgun nr. 55/1996. Nóvember 1998.

bingsályktun um tæknifrjóvganir (318). Afgreidd frá Sp. 14. des. 112. löggjafarping 1989. www.althingi.is/altext/ 112/s/0318.html 15.2.2005.

Tillaga til pingsályktunar um tæknifrjóvganir. Flm. Sigriður Lillý Baldursdóttir et al. 112. löggjafarping 1989. www. althingi.is/altext/112/s/0157.html 10.10.2005.

Tillaga til pingsályktunar um nýtingu stofnfrumna úr fósturvísum til rannsókna og lækninga. Flm. Jóhanna Sigurðardóttir et al. 131. löggjafarping 2004-2005. www.althingi.is/altext/ 131/s/0053.html 28.6.2005.

\section{The Nordic Council}

Medlemsförslag A 694/j. 28.9.1984. The Nordic Council Protocol 1987.

The Nordic Council Protocol 1987. Rekommendation 31/1986. The Nordic Council Protocol 1987.

\section{Norway}

Helsedepartementet. Helseminister Dagfinn Høybråtens innlegg ved behandling av Dok.nr.8:41 (2003-2004) om forslag om endring i bioteknologiloven. Odelstinget Tirsdag 11.05.04. http://odin.dep.no/hod/norsk/aktuelt/tal er/minister/042041-990055/dok- 
bn.html 20.9.2005 (Helsedepartementet 2004a).

Helsedepartementet. Oppnevning av

Dispensasjons- og klagenemnd for behandling i utlandet. Pressemelding nr. 47, 12.7.2004. http://odin.dep.no/ hod/norsk/aktuelt/pressesenter/pressem /042071-070258/dok-bn.html 12.3.2005 (Helsedepartementet 2004b).

Innst.O.nr.67 (1993-94). Innstilling fra sosialkomiteen om lov om medisinsk bruk av bioteknologi.

Innst.O.nr.71 (2003-2004). Instilling fra sosialkomiteen om forslag fra stortingsrepresentantene John I Alvheim og Harald T Nesvik om lov om endring i lov 5. desember 2003 nr. 100 om humanmedisinsk bruk av bioteknologi m.m. (bioteknologiloven).

NOU 1991:6. Om mennesker og bioteknologi. Sosialdepartementet.

Ot.prp.nr.64 (2002-2003). Om lov om medisinsk bruk av bioteknologi m.m. (bioteknologiloven). Det kongelige helsedepartement. Tilråding fra Helsedepartementet av 11. april 2003, godkjent i statsråd samme dag.

Sosial- og helsedirektoratet, Behandling av thalassemia major - Sosial- og helsedirektoratets vurdering 15.3.2004.

St.meld.nr.14 (2001-2002). Evaluering av lov om medisinsk bruk av bioteknologi. Helsedepartementet.

Vedtak nr. 443 i Stortinget, jf. Innst.S.nr.225 (2004-2005), jf. Dokument nr.8:64 (2004-2005), Møte 09.06.2005.

\section{Sweden}

Dir 1999:5. Barn i homosexuella familjer. Justitiedepartementet.

Ds 2000:51. Behandling av ofrivillig barnlöshet. Socialdepartementet. Stockholm 2000.
Ds 2004:19. Föräldraskap vid assisterad befruktning för homosexuella. Justitiedepartementet. Stockholm 2004.

Kristdemokraterna: Medicinsk-etiska frågor, 27.10.1998, www.kristdemokraterna.se/article.asp?Article_id=4886 17.3.2005.

Kristdemokraterna: Principprogram 2001, www.kristdemokraterna.se /principprogram/kd_principprg.pdf 17.3.2005.

Ministry of Justice: Homosexual partnership and adoption. Fact sheet. Ministry of Justice Ju 03.03e, March 2003. www.regeringen.se 20.4.2005.

Prop. 2001/02:89. Behandling av ofrivillig barnlöshet.

Prop. 2001/02:123. Partnerskap och adoption.

Prop. 2004/05:137. Assisterad befruktning och föräldraskap.

Socialstyrelsen: Assisterad befruktning 2002. Assisted reproduction. Results of treatment 2002. Socialstyrelsen, epidemiologiskt centrum. Statistik, hälsa och sjukdomar 2004:12.

SOU 1978:10. Barnets rätt 1: om förbud mot aga. Delbetänkande av utredningen om barnens rätt. Justitiedepartementet. Stockholm 1978.

SOU 1979:63. Barnets rätt 2: om föräldraansvar m.m. Delbetänkande av utredningen om barnens rätt. Justitiedepartementet. Stockholm 1979.

SOU 1983:42. Barn genom insemination. Betänkande av Inseminationsutredningen. Justitiedepartementet. Stockholm 1983.

SOU 1985:05. Barn genom befruktning utanför kroppen m.m. Betänkande av inseminationsutredningen. Justitiedepartementet. Stockholm 1985.

SOU 1995:5. Priorities in health care: Ethics, economy, implementation. Final report from the Swedish Parliamentary Priorities Commission. Stockholm 1995. 
SOU 2001:10. Barn i homosexuella familjer. Justitiedepartementet. Stockholm 2001.

SOU 2002:119. Rättslig reglering av stamcellsforskning. Delbetänkande från Kommittén om genetisk integritet. Stockholm 2002.

Statens medicinsk-etiska råd: Assisterad befruktning - Synpunkter på vissa frågor i samband med befruktning utanför kroppen. Statens medicinsk-etiska råd 1995-04-05. www.smer.gov.se/index. htm?lang=sv\&index $=4 \&$ url=yttranden. html 30.8.2005.

\section{Unpublished documents}

Conradsen, Inger Marie: Replacing Lost Certainty: The case of regulating Assisted Reproductive Technologies: A comparative study of Denmark and the United Kingdom. A doctoral dissertation. European University Institute, June 2002.

Kulawik Teresa: The Politics of Stem Cells in Sweden. Explaining Liberal Regulations in the Social Democratic State. Prepared for delivery at the EASST conference, Paris, August 2004. 


\section{Abbreviations}

$\begin{array}{ll}\text { AID } & \text { artificial insemination by donor } \\ \text { ART } & \text { assisted reproductive technology } \\ \text { BesI.O. } & \text { Beslutning i Odelstinget (Norway) } \\ \text { DI } & \text { donor insemination } \\ \text { Dir } & \text { Direktiv (Sweden) } \\ \text { Ds } & \text { Departementsserien (Sweden) } \\ \text { ESHRE } & \text { European Society for Human Reproduction \& Embryology } \\ \text { FER } & \text { frozen embryo transfer } \\ \text { HE } & \text { Hallituksen esitys (Finland) } \\ \text { ICSI } & \text { intracytoplasmic sperm injection } \\ \text { Innst.O. } & \text { Innstilling til Odelstinget (Norway) } \\ \text { IVF } & \text { in vitro fertilization } \\ \text { LaVM } & \text { Lakivaliokunnan mietintö (Finland) } \\ \text { NOU } & \text { Norges offentlige utredninger (Norway) } \\ \text { Ot.prp. } & \text { Odelstingsproposisjoner (Norway) } \\ \text { PGD } & \text { preimplantation genetic diagnosis } \\ \text { PGD-HLA } & \text { preimplantation tissue typing } \\ \text { Prop. } & \text { Proposition (Sweden) } \\ \text { SOU } & \text { Statens offentliga utredningar (Sweden) } \\ \text { St.meld. } & \text { Stortingsmeldinger (Norway) }\end{array}$




\section{Acknowledgements}

The writing of this report was an intense project. The entire project was to be completed in less than a year, which left approximately two months of research for each Nordic country. It could not have been done without a great deal of support and help from a great number of people.

I am most grateful to the Nordic Committee on Bioethics for giving me the opportunity to embark on this exciting and challenging endeavor. In particular, I wish to thank the chairwoman of the Committee, Associate Professor Ingileif Jónsdóttir, for her generous and untiring help with the chapter on Iceland. The members of the reference group, Dr. Mette Hartlev and Dr. Katarina Westerlund provided me with very useful comments on the report as well as valuable assistance with the chapters on Denmark and Sweden. Professor Susanne Lundin was also of indispensable help as Dr. Westerlund's predecessor at the reference group. The role of Dr. Salla Lötjönen and the Committee secretary Helena von Troil was crucially important. Their help and support was, in many ways, the heart and soul of this project.

The most rewarding and informative part of the project was the interviews of the more than thirty Nordic experts and actors in the field of assisted reproduction. I wish to thank them for sharing their insight and knowledge with me.

Most of all I wish to express my gratitude to my husband, Associate Director Dieter Burrell for his enormous contribution to this project. As a political scientist Dieter was able to provide me with invaluable advice, information, and contacts. Without his assistance and support this report might not have seen the light of the day.

Anjalankoski, October 2005

Riitta Burrell 


\section{Appendix}

Original names of central acts and governmental bodies

\section{Denmark}

Act on Abortion and Fetal Reduction Bekendtgørelse nr. 540 af 16 . juni 2004 om svangerkabsafbrydelse og fosterreduktion

Act on Artificial Fertilization - Lov nr. 460 av 10. juni 1997 om kunstig befrugtning som ændret ved lov nr. 427 af 10. juni 2003, lov nr. 69 af 4 . februar 2004 og lov nr. 240 af 5. april 2004

Act on the Establishment of an Ethical

Council and the Regulation of Certain Forms of Biomedical Experiments Lov nr. 353 af 3. juni 1987 om oprettelse af et etisk råd og regulering af visse biomedicinske forsøg

Act on the Danish Council of Ethics Lov nr. 440 af 9. juni 2004 om Det Etiske Råd

Act on a Scientific Ethical Committee System and the Handling of Biomedical Research Projects - Lov nr. 402 af 28. maj 2003 om et videnskabsetisk komitésystem og behandling af biomedicinske forskningsprojekter

Committee for Gene Technology Gensplejsningsudvalget

Committee on Gene Technology - Genteknologiudvalget

Committee on Ethical Problems Regarding In Vitro Fertilization, Artificial Insemination, and Fetal Diagnostics Udvalg om etiske problemer ved ægtransplantation, kunstig befrugtning og fosterdiagnostik

Danish Board of Technology - Teknologirådet
Danish Council of Ethics - Det Etiske Råd

National Board of Health - Sundhedsstyrelsen

Finland

Act on Registered Partnerships - Laki rekisteröidystä parisuhteesta 9.11.2001/950

Finnish Family Federation - Väestöliitto National Authority for Medicolegal Affairs - Terveydenhuollon oikeusturvakeskus

National Board of Health - Lääkintöhallitus

National Research and Development Center for Welfare and Health - Sosiaali- ja terveysalan tutkimus- ja kehittämiskeskus (STAKES)

\section{Iceland}

Act on Artificial Fertilization - Lög um tæknifrjóvgun nr. 55/1996

Act in Respect of Children - Barnalög nr. 76/2003

Child Act - Barnalög nr. 20/1992

Regulation on Artificial Fertilization Reglugerð nr. 568/1997 um tæknifrjóvgun með áorðnum breytigum skv. reglugerð nr. 585/1997

State Social Security Institute - Tryggingastofnun ríkisins

\section{Norway}

Act on Artificial Fertilization - Lov 12. juni 1987 nr. 68 om kunstig befruktning 
Act on the Medical Use of Biotechnology - Lov 5. desember 2003 nr. 100 om humanmedisinsk bruk av bioteknologi m.m. (bioteknologiloven) som endret ved lov nr. 45 av 25 juni 2004

Act Relating to the Application of Biotechnology in Medicine - Lov 5. august $1994 \mathrm{nr}$. 56 om medisinsk bruk av bioteknologi

Biotechnology Committee - Bioteknologiutvalget

Dispensation and Appeals Board for Treatment Abroad - Dispensasjons- og klagenemnd for behandling i utlandet

Ethics Committee - Etikutvalget

Norwegian Biotechnology Advisory

Board - Bioteknologinemnda
Norwegian Board of Health - Statens helsetilsyn

Sweden

Act Concerning Measures for Purposes of Research or Treatment Involving Human Ova - Lag (1991:115) om åtgärder i forskning- eller behandlingssyfte med ägg från människa

Act on In Vitro Fertilization - Lag (1988:711) om befruktning utanför kroppen

Insemination Act - Lag (1984:1140) om insemination

National Board of Health and Welfare Socialstyrelsen

Swedish National Council of Medical Ethics - Statens medicinsk-etiska råd 